\title{
Economic Literacy and Inflation Expectations: Evidence from a Laboratory Experiment
}

\author{
Mary A. Burke and Michael Manz
}

\begin{abstract}
:
We present new experimental evidence on heterogeneity in the formation of inflation expectations and relate the variation to economic literacy and demographics. The experimental design allows us to investigate two channels through which expectations-formation may vary across individuals: (1) the choice of information and (2) the use of given information. Subjects who are more economically literate perform better along both dimensions - they choose morerelevant information and make better use of given information. Compared with survey data on inflation expectations, fewer demographic factors are associated with variation in inflation expectations, and economic literacy in most cases accounts for demographic variation in expectations.
\end{abstract}

\section{JEL Classifications: E31, E37, E52}

Mary A. Burke is a Senior Economist at the Federal Reserve Bank of Boston. Her email address is mary.burke@bos.frb.org. Michael Manz is Head of the Section for International Finance and Financial Stability of the Swiss State Secretariat for International Finance. His email address is michael.manz@sif.admin.ch

This paper, which may be revised, is available on the web site of the Federal Reserve Bank of Boston at: http://www.bostonfed.org/economic/ppdp/index.htm

This paper presents preliminary analysis and results intended to stimulate discussion and critical comment. The views expressed herein are those of the authors and do not indicate concurrence by other members of the research staff or principals of the Federal Reserve Bank of Boston, the Board of Governors, or the Federal Reserve System. In addition, the views expressed in this paper do not necessarily reflect those of the Swiss State Secretariat for International Finance.

We would like to acknowledge Carl Nadler and Kevin Todd for extensive research assistance. For helpful comments and other important contributions, we thank Jeff Fuhrer, Geoff Tootell, Giovanni Olivei, Bob Triest, Anat Bracha, Julian Jamison, Michelle Barnes, Fabià Gumbau-Brisa, Jane Little, Stephan Meier, Tanya Rosenblat, Lena Drager, Steffan Ball, and seminar and conference participants at the Boston Fed, New York Fed, Brandeis University, and St. Louis Fed. We also wish to thank Mark Edington and the staff at the Harvard Decision Sciences Lab, staff and students at Roxbury Community College for participating in test experiments, and Deborah Bloomberg at the Boston Fed for facilitating our pre-tests.

This version: November 2011

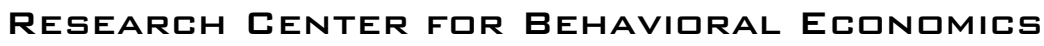




\section{Introduction}

While standard macroeconomic models assume that consumers' inflation expectations are rational and homogeneous, such expectations have been found to exhibit an upward bias on average and to vary significantly with demographic characteristics. Such behavior may hold implications for the successful conduct of monetary policy and the soundness of personal financial decisions, not to mention the predictive power of macroeconomic theory. The dearth of empirical evidence on the formation of inflation expectations contributes to a lack of consensus in monetary policy debates, as evidenced by recent disagreements over the impact on inflation expectations of quantitative easing by the Federal Reserve. ${ }^{1}$ In light of these implications, monetary policymakers have expressed growing interest in studying the process by which inflation expectations are formed at the individual level. Bernanke (2007), in particular, acknowledges the potential disconnect between real-world inflation expectations and those implied by a rational expectations framework, and calls for research into the open question of "...what factors affect the level of inflation expectations and the degree to which they are anchored?"

In this paper, we present new experimental evidence on heterogeneity in the formation of inflation expectations and relate the variation to economic literacy and demographics. The design of the experiment allows us to investigate two different channels through which expectations-formation may vary across individuals: (1) the choice of information used to predict inflation and (2) the use of given information. Both channels are likely to be relevant in the real world, where subjects must first choose, consciously or not, what information to refer to, and then how to process that information, when forming inflation expectations. We find that subjects who are more economically literate perform better along both of these dimensionsthat is, they choose more-relevant information and make better use of given information and therefore make better forecasts. In addition, heterogeneity in information-selection induces significant variation in the accuracy of inflation forecasts over and above the variation observed

\footnotetext{
${ }^{1}$ For examples of such debates, see FOMC minutes from January 28, 2009 and November 3, 2010 (among others during the same time period), as well as Bernanke (2007) and Dudley (2009).
} 
when information is controlled. Economic literacy helps to explain heterogeneity in inflationforecasting behavior that is not accounted for by other observable demographics and is not reducible to general educational attainment. Compared with previous studies of survey data on inflation expectations, we find that fewer demographic factors are associated with variation in inflation expectations and that economic literacy accounts for much of the apparent demographic variation in expectations. ${ }^{2}$

\section{a. Why an experiment?}

Survey data offer valuable information by polling consumers about inflation perceptions and expectations in real time. Survey methods also have their limitations. First, survey subjects have little incentive to make a good forecast, whereas in the real world there may be economic costs to making a poor forecast-although the salience of incentives attached to inflation forecasts is likely to vary with inflation itself. ${ }^{3}$ Second, and more important, survey instruments refer to actual economic conditions and therefore may not be able to access expectations under a wide range of macroeconomic scenarios. For example, the U.S. has experienced relatively low inflation in recent years and the salience of inflation may therefore be low in the current environment. Finally, survey methods are not well suited to determining how individuals select and process information when forming inflation expectations. For example, survey questions aimed at eliciting the types of information used to form expectations rely on introspection afterthe-fact and therefore the responses may be subject to psychological biases.

Our experiment mitigates these limitations in that (1) subjects are rewarded based on the accuracy of their forecasts and so face incentives to think carefully, (2) subjects form inflation expectations under a diverse set of macroeconomic scenarios, and (3) subjects' behavior reveals features of the expectations-formation process that cannot be readily ascertained via survey methods. While this process is of necessity circumscribed by the experimental design, we claim

\footnotetext{
2 Our measure of economic literacy encompasses aspects of economic literacy (for example, understanding of monetary policy) as well as financial literacy (for example, compound interest) and numeracy. See Section 2 for details.

${ }^{3}$ While consumers are rarely asked to make explicit inflation forecasts in real life, such forecasts are made at least implicitly in the context of many personal financial decisions.
} 
the design reveals important aspects of subjects' beliefs about what drives inflation and therefore something about how they might predict inflation in a real-world context.

In the experiment, subjects complete a set of inflation-forecasting exercises in a simulated economic environment. Payoffs are based on the absolute difference between the subject's forecast and the forecast derived from a macroeonomic model calibrated against historical U.S. data. In the first set of exercises, to assist their forecasts, subjects select from a menu of information sources of varying degrees of economic relevance. In a second series of exercises, the same subjects receive preselected, uniform information sets. This novel design allows us to investigate the contributions of both information selection and information processing to heterogeneity in the formation of inflation expectations.

\section{b. Relevant literature}

Previous studies of survey data have identified significant heterogeneity in inflation perceptions and expectations associated with demographic and socioeconomic characteristics. Bryan and Venkatu (2001a) find in a survey of Ohio consumers that women perceive higher rates of recent-past inflation than men do and predict higher future inflation than men, even after controlling for age, education, income, marital status, and race. ${ }^{4}$ Studies of consumer survey data in the U.S. (Bryan and Venkatu 2001b, Bruine de Bruin et al. 2010, Pfajfar and Santoro 2008, Souleles 2004), New Zealand (Leung 2009), England (Blanchflower and MacCoille 2009), and Ireland (Duffy and Lunn 2009) have all found that individuals with lower household incomes tend to have higher inflation perceptions and expectations than those with higher incomes, although a study of South African consumers finds the opposite (Kershoff 2000). Higher educational attainment and higher skill levels were also associated with lower inflation expectations in a number of studies (Bryan and Venkatu 2001b, Leung 2009).

One early explanation of demographic variation posited that consumers who purchase different baskets of goods would have different experiences with inflation and would form different

\footnotetext{
4 The same study reports similar gender differences in inflation expectations based on the nationally-representative University of Michigan consumer survey.
} 
inflation expectations based on such experiences (Jonung 1981). Against this hypothesis, Bryan and Venkatu (2001a) find that gender differences in inflation perceptions hold even for specific goods, such as gasoline, and Hobijn et al. (2008) find that demographic differences in experienced inflation are not large enough to explain observed differences in expectations. Malmendier and Nagel (2009) identify age-related heterogeneity in inflation expectations that is not explained by the age-specificity of the consumption basket. Pfajfar and Santoro (2008) find that the individual consumption basket influences inflation expectations among individuals of low socioeconomic status (SES), but no such influence was found among high SES individuals.

Bruine de Bruin et al. (2010) find that a measure of financial literacy (dominated by numeracy in particular) is associated with heterogeneity in inflation expectations, where differences in the types of information used to form expectations may help to account for such heterogeneity. Their survey data indicate that, in forming inflation expectations, less financially literate individuals are more likely to refer to their personal financial situation-rather than to aggregate data such as CPI inflation - than are more financially literate individuals. Less literate types were also more likely to exhibit positive forecasting errors. In sum, the existing survey evidence suggests that differences in the information sets individuals rely on to form inflation expectations may contribute significantly to heterogeneity in such expectations, despite the fact that individualized price indexes do not appear to be strong proxies for such information sets. Aside from Bruine de Bruin et al. (2010), however, there is very little direct evidence about what types of information different individuals deem most important when forecasting inflation.

There is a considerable literature in experimental psychology and experimental economics pertaining to the formation of expectations in context-free settings. In such experiments, subjects are typically shown a univariate time-series of a given length and asked to forecast what will happen next in the series (Becker, Leitner, and Leopold-Wildburger 2009; Hey 1994, Dwyer et al. 1993; Bloomfield and Hales 2002). ${ }^{5}$ These studies offer diverse findings and fail to agree strongly on matters such as the rationality of expectation formation and the use of various

\footnotetext{
${ }^{5}$ Additional papers of note in this literature include Bergmann (1988), Blomqvist (1989), Peterson and Reilly (1991), Beckman and Downs (1997), Heit (2000), Bolle (1988a), and Bolle (1988b).
} 
heuristic devices. Lawrence et al. (2006) and Roetheli (2011) find, however, that context matters for forecasting - that is, forecasting behavior does not appear to have consistent properties across different real-world contexts. Therefore, behavior in context-free experimental settings may not apply to the formation of inflation expectations.

Only a handful of experiments have focused on inflation expectations in particular. These include Pfajfar and Zakelj (2009), who find that experimental subjects exhibited a diverse set of behaviors - supporting diverse theoretical models - in forming inflation expectations within the context of a New Keynesian sticky-price model, with variation occurring both between and within subjects. Marimon and Sunder (1995) and Bernasconi and Kirchkamp (2000) both study experimental inflation expectations in the context of overlapping generations models, focusing on the extent to which forecasting behavior follows adaptive learning rules rather than embodying rational expectations. Adam (2007) finds experimental evidence that subjects adopt a "restricted perceptions equilibrium" when forecasting inflation, in the sense that their forecasts depend only on past inflation and not also on other available (and informative) macroeconomic data. Arifovic and Sargent (2003) study the formation of inflation expectations in the context of analyzing the emergence of various macroeconomic equilibria in a laboratory setting. Armantier et al. (2011) elicit inflation expectations among survey participants and examine the same subjects' behavior in an investment experiment in which payoffs depend on future inflation. They find that a significant share of subjects select investments that are consistent with their inflation expectations and that subjects whose behavior appears inconsistent with their expectations tend to score lower on a test of financial literacy and numeracy.

The focus of our experiment is different from nearly all of those mentioned above in two important respects. First, we wanted to elicit subjects' prior beliefs and habits with respect to the formation of inflation expectations, rather than determine whether subjects can learn about a particular model in the lab. ${ }^{6}$ Second, we are primarily interested in the microeconomic

${ }^{6}$ Roetheli (2011) also elicits subjects' prior habits concerning inflation expectations, with no opportunity for learning about a model. 
variation in inflation expectations and its observable determinants rather than in the extent to which individual and group behavior conforms to the rational expectations hypothesis or some alternative model. ${ }^{7}$

Our experimental design differs in several key respects from that of previous experiments that elicited inflation expectations. First, as explained above, rather than always showing subjects specific data such as past inflation, in some exercises we offer subjects a choice of data. Second, in order to prevent subjects from learning about the model during the course of the exercises, we never inform them of the "correct" inflation forecast in a particular exercise. Third, in our setting, future inflation outcomes are determined by the model and not influenced by subjects' expectations. This last design feature is consistent with the notion that, in the real world, people are likely to act as if their individual expectations do not affect future inflation.

\section{Experimental Design}

The experiment consisted of six components, listed in order: (1) a brief set of questions related to past and future U.S. inflation, (2) a series of eight (incentivized) inflation-forecasting exercises pertaining to a simulated economy and offering a menu of information sources to choose from, (3) a set of free-response questions about how subjects selected information in the preceding exercises, (4) a series of nine (incentivized) inflation-forecasting exercises in a simulated economy in which subjects received information of our choosing, (5) a set of 16 (incentivized) multiple-choice questions designed to measure economic and financial literacy, and (6) a demographic questionnaire. Each subject completed each phase of the experiment. Detailed instructions were given prior to each phase of the experiment. Prior to the forecasting exercises, subjects worked with a practice interface and took an ungraded quiz that indicated whether they understood the instructions. Answers to the quiz were revealed immediately, just before

${ }^{7}$ We focus on the rationality of expectations-formation in our experiments in a forthcoming companion paper. 
subjects began the forecasting exercises. We elaborate on each of the experimental components immediately below. ${ }^{8}$

\section{a. Questions about past and future U.S. inflation}

After brief introductory remarks, subjects were presented with an initial multiple choice question seeking a definition of inflation. Immediately following this question, subjects were shown the correct answer to the question, as follows: "Inflation is the rate of increase in the overall price level of goods and services in an economy." Examples were given of rates of inflation expressed as annual percentage changes in the price level, including both positive and negative values.

Then we asked subjects to provide an estimate of the average annual U.S. inflation rate during the previous five years. Next, we asked two questions modeled on the University of Michigan's inflation-expectations question: the first elicited a forecast of inflation in the ensuing 12 months, and the second a forecast of the annual inflation rate five years into the future.

\section{b. Inflation-forecasting exercises}

The core of our study-the actual experiment-consists of the series of inflation-forecasting exercises for the simulated economy. In each exercise, the objective was to forecast "future" inflation, either 1-year ahead or, in some exercises, five years ahead. Subjects were instructed to express forecasts in percentage terms, using up to two digits after the decimal point. Instructions stated that all situations were hypothetical and that subjects were not attempting to forecast real-world inflation. However, subjects were instructed that the data they were shown behaved as if they came from a real economy. They were told, correctly, that the situations they face were generated by a model that was calibrated against U.S. historical experience in the late $20^{\text {th }}$ century. This model can be used to generate forecasts of future inflation--for example, it can be used to predict the inflation rate at time $t+1$ from the vantage point of time $t$, although realized inflation as of $t+1$ may deviate from this forecast based on random shocks that occur

${ }^{8}$ The complete text of the instructions and examples of forecasting exercises from the experiment are available by request from the authors. 
after the forecast is made. Subjects' guesses were judged (and payoffs determined) against the model's predicted inflation rate as of the "current" period within the given economic scenario, rather than by the future value of inflation that is revealed as the model economy's next period is played out. We chose this payoff method in order to avoid the possibility that poor forecasts (from an ex ante standpoint) would be rewarded on the basis of random realizations.

Quantitatively, the payoff per exercise was computed as the maximum between zero and the quantity $\left(\$ 45-\$ 15 \times \operatorname{abs}\left(f^{s}-f^{m}\right)\right)$, where $f^{s}$ denotes the forecast entered by a subject and $f^{m}$ denotes the corresponding prediction of the model. Thus, the maximum payoff a subject could achieve on a given exercise was $\$ 45$ and the minimum payoff was zero, the latter earned by subjects who missed the model's prediction by three or more percentage points (in absolute terms). ${ }^{9}$ The combined payoff for all forecasting exercises was computed as the average of the payoffs earned in each exercise. ${ }^{10}$ Subjects also earned a $\$ 10$ flat fee just for showing up and staying to the end of the experiment.

To prevent learning about the model in the course of the experiment, subjects were not informed of the payoff they received (nor of the correct forecast) on any specific forecasting exercise. However, to maintain motivation, subjects were shown, at four points within the simulated-economy forecasting exercises, the running cumulative (average) payoff from the exercises that they had completed to that point.

Before making their forecasts, subjects were given the opportunity to access information about the current state of the simulated economy. Subjects were told that at least some, though not necessarily all, of the information sources provided were indicative of future inflation. During the course of the experiment, information was presented in two different ways. In the first eight exercises, which we term "endogenous," subjects were not shown any of the data series automatically. Instead, they were shown a menu of seven items, termed information "sources" within the experiment, and they were instructed that they could view up to three sources per

\footnotetext{
9 The truncation at zero avoided the problem of negative payoffs.

${ }^{10}$ We chose to provide a high payoff per question and average the outcomes in order to increase the salience of the per-question payoff.
} 
exercise. In the remaining nine "exogenous information" exercises, subjects were given preselected information. We placed the endogenous exercises prior to the exogenous exercises so that our selection of data sources in the latter would not influence subjects' choice of information in the former.

The model used to generate the simulated economic scenarios is a six-equation, reduced-form model of the U.S. economy that represents a simplified version of the model used by the Federal Reserve Bank of Boston to make macroeconomic forecasts. Dependent variables in the model consisted of the output gap, core CPI inflation, headline CPI inflation, the Federal Funds rate (based on a Taylor rule), the real oil price, and the unemployment rate gap. We used the model to generate hypothetical time-series for these variables, based on selecting random shocks from the empirical shock distribution estimated for the United States over the time period 19842007..$^{11}$

From the simulated time series, we selected snapshots of contemporaneous data pertaining to headline CPI inflation, the unemployment rate (as a level), the federal funds rate (termed "short-term interest rate" in the experiment), and the annual rate of inflation in the price of oil. ${ }^{12}$ To the data produced by the model, we appended hypothetical data on annual milk-price inflation and the annual population growth rate. These data were drawn from actual historical time series for the United States and chosen so that correlations with model-generated variables were within the normal historical range. For a given exercise, we selected three consecutive years of data on each of the six variables. Time was indexed such that the last value in each sequence corresponded to the "current" year, denoted $t=0$, with earlier years denoted $t=-1$ ("one year ago"), $t=-2$ ("two years ago"), and so on. In the case of headline inflation, we included an additional set of three data points, with periods $t=-5, t=-4$ and $t=-3$. Thus, for each exercise, we selected a set of seven 3-period time series (in graph form, with data values labeled) indicating

\footnotetext{
11 Shocks to some variables (headline inflation and the fed funds rate) were set to zero to avoid extended periods of deflation and/or negative values of the fed funds rate. Parametric assumptions were as follows: inflation target set at 2.5 percent, potential growth at 3 percent, equilibrium real federal funds rate at 2 percent, and natural rate of unemployment (NAIRU) at 5.25 percent.

12 The model frequency was quarterly; we converted to annual data by calculating year-over-year changes or (for levels) annual averages.
} 
recent conditions in the hypothetical economy. The set of scenarios was selected with an eye to generating variation in the macroeconomic conditions presented and in the degree of difficulty of making each forecast.

In each endogenous exercise, subjects could access up to three out of the seven information sources. The menu of sources was identical across exercises, but the information content was (potentially) different. Each source was labeled with a description of its contents, such as "recent inflation." There were no explicit costs of viewing a source other than the time cost, as subjects had a limit of two minutes to complete each forecasting exercise, and the opportunity cost of not viewing another source. Subjects could view only one source at a time in the same window, but were able to toggle back and forth between the selected sources within the time limit. The program kept track of the entire sequence of information viewing, including time spent viewing each source. When a given exercise was completed - which occurred when the subject entered a number for the forecast and pressed a "confirm" button-the next exercise appeared and subjects again had the option to select from the menu of sources. The order of information sources was scrambled among subjects so as to prevent order effects, but each individual subject saw the same order in each exercise to prevent confusion. We find no evidence that the order of sources influenced the frequency with which they were chosen.

Endogenous exercises were divided into one-year horizon forecasting exercises (five of eight) and five-year-horizon forecasting exercises (three of eight). Subjects were prompted when horizons shifted between sets of exercises, and the horizon was labeled within each exercise. In each of the one-year-horizon forecasting exercises, the data used in the different exercises were different from one another-that is, taken from non-adjacent time periods of the same simulated time-series or from a separate time-series. However, the data for the five-yearhorizon exercises in each case were identical to the data in one of the one-year-horizon exercises. The idea was to observe whether forecasts differed with the horizon, controlling for the data. Based on how data were presented, it would have been very difficult to recognize that the data were the same. Once a given exercise was completed, subjects could not revisit it. 
In the nine "exogenous information" exercises, all subjects were shown the same pre-selected information prior to making their forecasts. In all but one exercise, we presented two 3-point data series representing two variables, where one of the sources was recent inflation. In one exercise, we presented only one 3-point data series, which did not show inflation. Again, exercises were split between one-year (six of nine) and five-year (three of nine) horizon forecasts, where again each of the five-year forecasting exercises involved data that duplicated one of the one-year horizon scenarios.

Within the set of endogenous exercises and, separately, within the exogenous set, subjects were assigned to one of two ordering groups: some subjects saw all the one-year-horizon exercises within a set first and then all the five-year-horizon exercises, and a second group received the five-year exercises first, followed by the one-year exercises. Randomization into groups was conducted separately for the endogenous set and the exogenous set. Therefore, a given subject received the 17 inflation-forecasting exercises in one of four possible unique sequences.

\section{c. Free-response questions}

Immediately following completion of the endogenous forecasting exercises, and prior to completing the exogenous exercises, subjects were asked two questions about their behavior in the endogenous exercises: "Other than the available sources, what additional information would have been helpful to you in making your forecasts?" and "Considering the average number of information sources you chose, tell us why you chose this many sources."

\section{d. Economic literacy questions}

The questionnaire on economic and financial literacy consisted of 16 multiple-choice questions (including the question on the definition of inflation mentioned above and asked prior to the forecasting exercises) covering knowledge of monetary policy, basic concepts of personal finance, and numeracy. Many of our financial literacy questions or slight variations thereof have been used and tested in previous studies, including van Rooij, Lusardi, and Alessie (2007) and 
the Jump\$tart High School Survey of Financial Literacy. ${ }^{13}$ Each question was followed by a menu of four answers, and subjects were asked to mark the single answer they deemed correct. Each correct response received a payoff of $\$ 0.20$, while incorrect answers and unanswered questions received a payoff of $\$ 0$. The total payoff for the literacy quiz was the sum of payoffs per question. The complete questionnaire is provided in the appendix.

\section{e. Demographics questionnaire}

The information we requested in the demographics questionnaire included age, sex, ethnicity, household income, current employment situation, and both own and mother's educational attainment. Subjects were also asked whether or not they had ever taken a class in economics or personal finance, to what extent they were interested in politics or economics, and to what extent they had experience with investing in financial markets. Racial categories included white, African-American or black, Hispanic, Asian, Native American, and other. Subjects could list more than one race, and those who did are placed in a separate "multiracial" category for purposes of empirical analysis. Income choices consisted of 7 discrete ranges, which were collapsed into four groups in the empirical analysis. For educational attainment (both own and mother's), subjects selected from the choices "high-school diploma or less," "some college but no degree," "associate's degree," "bachelor's degree," and "advanced degree," where examples of the latter (Ph.D., M.D., Master's) were given. In the empirical analysis we combine the “associate's degree" responses (actually just a single response) and "some college" responses to form the category "some college."

\section{Description of Subject Pool and Economic Literacy Scores}

We conducted 5 separate sessions of the experiment, following pre-testing conducted at the Boston Fed. The first session was a test run that took place in a computer lab at Roxbury Community College (in mid-November 2009) in Boston and consisted of 13 subjects, all students at the college. During this test run, we determined that a number of subjects did not

\footnotetext{
${ }^{13}$ Jump\$tart Coalition Survey of Personal Financial Literacy Among Students, 2008.
}

http://www.jumpstart.org/survey.html 
understand the instructions for the inflation-forecasting exercises. Following this experience, we improved the instructions and added an instructions quiz. With this revised design, in December 2009 we conducted four sessions at the Harvard Decision Sciences Laboratory on the campus of Harvard University. The subject pool across the four sessions at Harvard numbered 137 and included Harvard students as well as non-students. In the analysis that follows, we use only data generated by the 137 subjects from the Harvard sessions. ${ }^{14}$

\section{a. Demographics}

Descriptive statistics for the sample subjects are shown in Table 1. Mean age was 29, reflecting the presence of non-students in addition to students; 61 percent of subjects were female and 82 percent were born in the United States. The racial/ethnic shares were 60 percent white, 11 percent black, 14 percent Asian, 2 percent Hispanic (representing only three subjects), ${ }^{15} 9$ percent multiracial, and 4 percent other. Income responses fell into four categories: 45 percent had household incomes below $\$ 40,000$ per year, 19 percent between $\$ 40,000$ and $\$ 79,999,19$ percent between $\$ 80,000$ and $\$ 149,999$, and 15 percent $\$ 150,000$ or greater. (Histograms of the sample distributions of age and educational attainment are shown in Figures A1-A2, in the Appendix.) Regarding own educational attainment, 7 percent of subjects had only a high school diploma or less, 39 percent had either some college or an associate's degree, 39 percent a bachelor's degree, and 15 percent an advanced degree. Regarding mother's education, 15 percent reported attainment of high school or less, 44 percent some college or an associate's degree, 34 percent a bachelor's degree, and 34 percent an advanced degree.

\section{b. Economic literacy and its determinants}

Table 2 describes the economic literacy scores. Potential scores on the quiz ranged from zero to 100 percent. The mean score was 66 percent, with a range from 13 percent to 100 percent, and the standard deviation was 19 percentage points. Common factor analysis strongly

\footnotetext{
${ }^{14}$ In all regression models, we dropped one subject due to a missing value for gender. As necessary in each model, we also dropped one or two outlying observations that distorted results.

${ }^{15}$ Because the number of Hispanic subjects was small, we will not emphasize this factor in the ensuing analysis, even when results are statistically significant.
} 
suggests that there is only one underlying latent factor that drives the common variance among the 16 items of the economic literacy questionnaire. We are inclined to interpret this single common factor as reflecting economic and financial literacy. ${ }^{16}$ Cronbach's alpha for the questionnaire was 0.74 , above the widely used threshold of 0.70 for acceptable reliability.

To assess the relationship between demographic factors and our literacy measure, we ran an OLS regression of literacy scores against demographic and socioeconomic characteristics. Results are shown in Table 3 (standard errors are shown in parentheses). The model in the second column includes the indicator ("economics course") for whether subjects had taken an economics or finance course. Robust results (significant at the 5 percent level or better) include the following: women have lower scores than men, by about 7 percentage points on average; blacks have lower scores than whites by about 11 percentage points. These race and gender differences are noteworthy, given the numerous controls for other factors in the model. Higher educational attainment is associated with significantly higher scores - a bachelor's degree raises the score by about 15 percentage points and an advanced degree has an even stronger effect, raising the score by roughly 25 points. Those who reported having taken at least one course in economics or finance have significantly higher literacy scores, by 13 points. Neither income nor mother's education appears to be related to the literacy score in our sample.

\section{Experimental Results}

\section{a. Inflation expectations in the simulated-economy setting}

Figure 1 shows the distribution of inflation forecasts across all subjects and all forecasting exercises. Values are truncated - from below at -5 and from above at 10 -in order to illustrate the clustering of forecasts at whole number and half-number values. ${ }^{17}$ Among integer values, 5 percent was the most frequent forecast, followed by 2 percent and 4 percent. In the full distribution (barring only extreme outliers as described above), the average forecast was 3.1 and

\footnotetext{
16 We followed the common rule of retaining only factors with eigenvalues greater than one. Specifically, the first factor had an eigenvalue of 3.03 and accounted for 80 percent of the common variance among items, while the second factor had an eigenvalue of only 0.69 , accounting for 18 percent of common variation. More details on the results of factor analysis are available from the authors on request.

${ }_{17}$ Bars at -5 and 10 show total mass less than or equal to (or greater than or equal to) the endpoint values.
} 
the median was 2.5. The aggregate distribution reflects both within-subject variation (across exercises) and between-subject variation in forecasts (for a given exercise). Therefore the multimodality and non-normality of the distribution are not surprising. ${ }^{18}$

The distribution of individual (signed) inflation-forecasting errors across all exercises (see histogram in Figure 2) exhibits a positive bias at the mean (0.87), a median of 0.17, a rightward skew, and excess kurtosis. Figure 3 shows kernel density plots of the (signed) error distributions for two separate sets of exercises: the set of all six five-year-ahead forecasting exercises and the set of six one-year-ahead forecasting exercises that involved the same data. Among this set, we find that the forecast horizon has no significant effect on the average error (across subjects) per exercise.

\section{b. Demographics, economic literacy, and forecasting performance}

Here we investigate whether demographic factors and/or economic literacy scores predict variation in forecast errors in our simulated-economy forecasting exercises. To judge inflation bias, we compute the average (signed) forecasting error across all exercises, by subject. ${ }^{19}$ (A histogram of this variable is given in Appendix Figure A3.) We adopt a specification that is quadratic in the literacy score because this specification performs better than specifications in which literacy enters either linearly or as discrete categories (such as quartiles). Results are shown in Tables $4 \mathrm{a}$ (regular coefficients) and $4 \mathrm{~b}$ (standardized or beta coefficients). Column 1 of Table 4a shows results of an OLS model that includes just the demographic factors, excluding literacy. In this model, the only factor that has a significant effect ( $p$ value .05 or lower) on mean inflation bias is black race, which increases the mean forecast error by 0.75 percentage points. When economic literacy is added to the model (column 2), the black racial effect becomes insignificant, indicating that blacks' lower economic literacy (seen in Table 3) accounts for their higher forecast errors. Economic literacy reduces a subject's mean forecasting error significantly,

\footnotetext{
${ }^{18}$ In the regression analysis, we are typically dealing with the distribution of mean (within-subject) forecasting errors and other summary statistics on within-subject behavior, which conform more closely to normal distributions.

19 Alternatively, as in Duffy and Lunn (2009), we can construct a categorical measure of inflation bias based on the percentage of forecasts in which a subject overestimates inflation by a discrete margin. Using the same regression specification as for mean signed errors, results are qualitatively robust.
} 
but the marginal effect becomes weaker (in absolute terms) as literacy increases. At a literacy score of 47 percent (one standard deviation below the mean), a one-percentage-point increase in the literacy score would reduce the mean forecast error by 0.04 percentage points; while at the mean literacy score the analogous reduction in the mean error is just 0.008 percentage points. ${ }^{20}$ Economic literacy also adds considerable explanatory power to the model, as seen in the substantial increase in the (adjusted) R-squared value between columns 1 and 2.

To judge the accuracy of forecasts, we computed the within-subject mean absolute forecasting error (MAE) across exercises. (Histogram provided in Appendix Figure A4.) Using this measure as the dependent variable, we ran OLS regressions using the same sets of regressors as in the previous models (results shown in Table $4 \mathrm{a}$ and $4 \mathrm{~b}$, columns 3 and 4 ). In the model excluding economic literacy, black subjects had significantly larger mean absolute errors than whites, but again the effect becomes smaller and insignificant when literacy is included. Two other factors have significant effects only when literacy is excluded: age 32 or older (higher MAE), and having a mother with an advanced degree (lower MAE). However, the opposite holds for the effects of Asian race and having "some college," where in both cases we observe higher MAE values only after controlling for economic literacy. Economic literacy has significant negative, but diminishing, effects on the within-subject mean absolute error. At a literacy score of 47 percent, a one-percentage-point increase in the literacy score would reduce the mean absolute error by 0.035 percentage points; while at the mean score the analogous reduction in the mean error is 0.015 percentage points. ${ }^{21}$ Again, the addition of economic literacy increases the Rsquared value considerably, and more so in the model of absolute errors than in the model of signed errors. ${ }^{22}$

Analysis of standardized coefficient estimates (Table $4 \mathrm{~b}$ ) indicates that the effects of economic literacy are greatest, in terms of standard deviations, in the case of mean (signed) forecasts errors. Standardized effects of literacy on the mean absolute errors are almost as great, however,

\footnotetext{
${ }^{20}$ Under the quadratic specification, the marginal effect of literacy on the signed forecast error becomes positive at a literacy score of about 72 percent.

${ }^{21}$ Under the quadratic specification, the marginal effect of literacy on the mean absolute forecast error becomes positive at a literacy score of about 80 percent.

${ }^{22}$ In Tables $4 \mathrm{a}$ and 4b, reported standard errors are robust and, consequently, R-squared values are unadjusted.
} 
indicating that literacy improves accuracy to a large extent by mitigating the tendency to overestimate inflation.

\section{c. How literacy matters: selection of information vs. use of given information}

Thus far, results indicate that subjects who are more economically literate have lower mean absolute errors across the combined set of exercises. In the exogenous-information exercises, economic literacy could have influenced performance only through its effects on the use of given information. In the endogenous-information exercises, economic literacy might have contributed to more-accurate inflation expectations both through its influence on information selection and through its influence on the use of information once selected. Comparing the influence of economic literacy between the two types of exercises may therefore tell us something about the importance of each of these two channels.

Results are shown in Table 5. First consider the mean absolute errors (MAE) in the set of exogenous forecasting exercises only (column 1). Adopting the same regression specification as in Table 4a, column 4, (described above), but restricted to the exogenous exercises, we observe that economic literacy reduces the MAE significantly, with effects of diminishing magnitude. ${ }^{23}$ At the average literacy score of 66 percent, a one-percentage-point increase in the score would lower the MAE of the inflation forecasts by about 0.016 percentage points, all else constant. Beginning from a score of 47 percent or one standard deviation below the mean, the marginal effect of economic literacy would be 0.038 percentage points. For the endogenous exercises (column 2), economic literacy has a somewhat stronger effect: at the average literacy score, a one-percentage-point increase in literacy lowers the MAE by .023 percentage points, and at a score of 47 percent, the marginal effect is 0.055 percentage points. ${ }^{24}$

The advantage conferred by economic literacy in the exogenous-information forecasts indicates that subjects who were more economically literate were better at exploiting the given

\footnotetext{
${ }^{23}$ Based on the quadratic fit, the marginal effect reaches zero at a score of about 80 percent and then becomes positive but small. A reasonable interpretation is that the marginal effects of literacy on the MAE are close to zero for literacy scores of 75 and above.

${ }^{24}$ Again, the marginal effect of economic literacy becomes zero at a score of around 80 percent and then becomes positive.
} 
information than were less-literate subjects. The finding that economic literacy has greater effects (in absolute terms) on forecast accuracy in the endogenous-information than in the exogenous-information exercises suggests that (1) selecting relevant information was an important factor in performance on the endogenous exercises and that (2) more-literate subjects tended to select more-relevant information in addition to making better use of given information.

The importance of the information-selection channel is also evidenced by the fact that the variance of forecasting performance across subjects (measured by the variance of MAEs) is more than 2.5 times as great in the endogenous-information exercises as in the exogenousinformation exercises-the respective variances are 1.84 and 0.71 . (Histograms of these respective distributions are shown in Appendix Figures A5 and A6.) By giving all subjects the same information in the exogenous-information treatment, the scope for variation in performance was dampened - the playing field was leveled to a certain extent. However, the variation need not have been greater in the endogenous-information treatment if all subjects had held similar beliefs about what information was most relevant for forecasting inflation.

Given the larger variance of MAEs in the endogenous-information exercises, the effect of economic literacy on the MAE is actually smaller - when measured in relation to the variancein the endogenous-information exercises than the exogenous-information exercises. Taking a one-standard-deviation band around the mean literacy score, the range of predicted MAEs in the endogenous exercises constitutes roughly two-thirds of a standard deviation, and in the exogenous exercises the analogous range of MAEs represents three-quarters of a standard deviation. This comparison does not detract from the finding that economic literacy confers a greater advantage in absolute terms in the endogenous exercises; it merely reflects the fact that other (mostly unobserved) factors lend additional variance to outcomes in the endogenous case.

\section{d. Importance of monetary literacy vs. financial literacy and numeracy}

Because our measure of economic literacy encompasses knowledge of macroeconomics (mostly monetary policy) in addition to financial literacy and basic numeracy, it is important to 
determine whether, for example, proficiency in one of these subject areas alone accounts for the variation in forecasting performance. If so, policy should emphasize, for example, mathematics education more than economic education. To assess the relative importance of different skill sets in driving our results, we identify subsets of the literacy quiz that can be classified, alternately, as measuring either "monetary literacy," encompassing knowledge of macroeconomic concepts related to monetary policy, financial literacy, or pure numeracy devoid of economic context. Out of 16 total questions, seven questions pertain to monetary literacy, seven questions pertain to financial literacy, and two questions capture pure numeracy. ${ }^{25}$ We then regress the mean absolute error against the standard demographic controls (as in the models in Table 4a.), but instead of using the subject's overall literacy score, we separately include (as both linear and quadratic terms) the subject's score on each of the three knowledge subsets just described.

Results shown in Table 6 indicate that both monetary and financial literacy have negative associations with the mean absolute forecast error. Coefficients on both linear and quadratic terms are statistically significant (p-values 0.05 or lower) for each of these score subsets, indicating diminishing (absolute) marginal effects. The effect of the numeracy score is negative and insignificant ( $\mathrm{p}$-value 0.12 ), although the lack of significance may simply reflect the small number of pure numeracy questions. The results suggest that both monetary literacy and financial literacy contribute independently to forecasting performance, while numeracy may or may not be an important additional factor.

\section{e. Formation of inflation expectations: selection of information in endogenous exercises}

Figure 4 summarizes subjects' choice of information sources in the endogenous exercises. For each individual and each information source (such as "current and recent inflation," consisting of the three most-recent values of inflation), we computed the share of exercises in which the subject picked the given source, computing the shares separately for one-year-ahead forecasting exercises and five-year-ahead exercises. The average choice rates across individuals (by forecast

\footnotetext{
${ }^{25}$ The list of questions of each type is provided in the appendix, along with the text of each question.
} 
horizon) are shown in Figure 4. For each forecasting horizon, the choice rates across sources sum to three (rather than one) because each subject could select up to three sources per exercise. Because subjects had the option to select fewer than three sources per exercise, we also show the residual category of "missed choice opportunities," which refers to the average rate at which subjects chose not to select an additional source when the option was available. ${ }^{26}$

Within the context of the macroeconomic model used to generate the data in the forecasting exercises, the single data source-encompassing three data points - with the greatest predictive power for one-year-ahead inflation is recent inflation, followed by the unemployment rate, the federal funds rate, earlier inflation, and oil-price inflation. ${ }^{27}$ The most frequently selected source in the experiment, by far, was "current and recent inflation," selected by the average subject in 84 percent of the one-year-horizon exercises and in 82 percent of the five-year-horizon exercises. While these rates are high, as we might expect, they nonetheless indicate that the average subject chose not to view recent inflation in 16 percent of (one-year-horizon) exercises. There was considerable variation between subjects in the inflation-rate choice, however, as the standard deviation of the choice rate for "current and recent inflation" was 26 percentage points.

"Earlier inflation" was the second-most-popular source at both forecasting horizons, and was more frequently selected during the five-year-horizon exercises (average choice rate 57 percent) than the one-year-horizon exercises (42 percent). The remaining sources were ranked in the following order for the one-year exercises, not including missed opportunities: milk-price change (38 percent), oil-price change (37 percent), short-term interest rate (32 percent), unemployment rate (27 percent), and population growth rate (8 percent). In the five-year-

\footnotetext{
${ }_{26}$ The maximum potential value of this "missed opportunity" rate per individual is three (or 300 percent), which would apply to a subject who chose zero sources in every exercise. For actual sources (such as "oil price inflation"), the maximum potential choice rate is one (100 percent), which would apply to an individual who chose the given source in every exercise.

27 The predictive power of a data source is ranked by comparing mean absolute prediction errors from regressions of the model's year-ahead inflation forecast against all possible sets of three data sources (three data vectors) over a simulated 622-year time series (since subjects could select only three sources at a time). The regression with the lowest mean prediction error identifies the best set of three sources; from the regression with the second-lowest prediction error, we narrow the list down to the top two sources (those that appear in both regressions), and so on, moving down the list of regressions ranked by mean prediction error.
} 
horizon exercises, the unemployment rate and short-term interest rate traded places in the rankings and the choice rate for population growth was greater (at 14 percent) than in the 1year-horizon exercises. The "missed opportunities" rates imply that the average subject selected about 2.7 sources per exercise (for either forecasting horizon), which means that most subjects chose the maximum 3 sources in all or most exercises.

Next, we consider the determinants of the individual choice rate (defined above) for "current and recent inflation," which we term simply "inflation" in the text that follows, because this measure represents a good indicator of "informed" or "rational" choice of information. Subjects who did not select inflation would have been at a sharp disadvantage compared to those who did, and selecting inflation inconsistently (rather than on every exercise) would suggest some uncertainty on the part of the subject concerning their knowledge of macroeconomic relationships. Results are shown in Table 7. Including only the demographic and socioeconomic factors (omitting economic literacy-see column 1), members of older age groups are significantly less likely to select inflation than those in the youngest group, while moreeducated subjects (bachelor's degree or higher) are more likely to view inflation, as are those with a mother who earned a bachelor's degree (mother's advanced degree has a marginally significant effect). Blacks were less likely to view inflation than whites at a marginal significance level.

When the economic literacy score and its square are added to the model (column 2), we observe that a higher literacy score is associated with a greater tendency to select recent inflation, albeit with diminishing marginal effects, and literacy adds considerable explanatory power. ${ }^{28}$ The coefficients on black race, bachelor's degree, and advanced degree all become insignificant, suggesting that demographic differences in literacy are driving the prior results. The effects of age remain significant. The effect of having a mother with a bachelor's degree is robust in both significance and magnitude, while the effect of mother's advanced degree becomes insignificant. Asian subjects select inflation at a significantly lower rate than whites, but only

\footnotetext{
28 Adjusted R-squared values are 0.58 in column 2 and 0.39 in column 1 . The model that is quadratic in economic literacy performs better than one that is linear or one that involves dummies for quartiles of the literacy distribution.
} 
after controlling for economic literacy. The results indicate that literacy is an important factor for the selection of inflation, although not the only factor, and that this relationship represents one of the mechanisms by which more-literate subjects achieved more-accurate inflation forecasts on average.

In addition to selecting inflation at a higher rate, more literate subjects chose a greater number of sources on average per exercise than less literate subjects and spent significantly more time deliberating on each exercise (within the two-minute limit), controlling for other factors (results not shown).

\section{Relevance of Experimental Performance to Real-World Forecasting Behavior}

It is natural to ask whether a subject's performance in the experimental setting provides meaningful information about the same subject's capacity to forecast real-world inflation. To address this issue, we consider three different sources of evidence. First, we describe the correlations between performance in the simulated-economy exercises and the real-world forecasting exercises. Second, we analyze the impact of economic literacy on performance in the real-world exercises. Finally, we analyze answers to free-response questions, a step that helps us to determine whether the information provided in the experiment corresponds to the types of information subjects would rely upon in making inflation forecasts in the real world.

\section{a. Real-world forecasts and their correlation with experimental forecasting performance}

Figure 5 shows the mean and median values of subjects' perceptions of average U.S. inflation during the past five years, as well as mean and median values of their forecasts of U.S. inflation, including one-year-ahead (next 12 months) and five-year-ahead forecasts. ${ }^{29}$ For comparison, the figure shows the same statistics for inflation forecasts (made at nearby dates) made by University of Michigan survey subjects (for 1-year-ahead inflation and for inflation "5 to 10 years ahead"). Figures A7 through A9 (in the appendix) show histograms of the respective

\footnotetext{
${ }^{29}$ In all reports of inflation perceptions and forecasts, whether pertaining to the U.S. economy or in the simulatedeconomy exercises, we eliminated observations in which inflation values were either below -10 percent or above 50 percent.
} 
distributions of our subjects' perceptions (past five years) and forecasts (one-year-ahead and five-years-ahead) of U.S. inflation. ${ }^{30}$

The mean estimate by our subjects of average U.S. inflation during the five years preceding the experiment (December 2004-December 2009) was 4.4 and the median estimate was 3.5 (all figures rounded to nearest tenth of a point), while the actual value (based on the headline CPI) was 2.5. The mean and median forecasts by our subjects (recorded in December 2009) of U.S. inflation one-year- ahead were 2.4 and 1.5, respectively, values that were significantly lower than the corresponding values from the Michigan survey (4.8 and 3.0, respectively). Subsequent inflation data show that headline CPI increased by about 1.3 percent between December 2009 and December 2010. Inflation forecasts for five-years ahead by our subjects displayed a mean value of 6.8 and median of 4.4, values considerably higher than the corresponding figures from Michigan. The larger values for five-year-ahead inflation may reflect misunderstanding of the question as referring to cumulative inflation. Only later in the experiment, in the instructions for the simulated-economy forecasting exercises, did we explain the concept of annual inflation five years in the future.

Considering the accuracy of perceptions of average U.S. inflation over the previous five years, we computed the error by taking the absolute value of the difference between the subject's perception and the average annual CPI inflation rate over the previous five years. The correlation between this error and the subject's mean absolute error (MAE) across all simulated forecasting exercises is positive and statistically significant, at 0.354 (p-value 0.00 ). For the oneyear-ahead forecasts of U.S. inflation, we computed the absolute forecast error, using the realized U.S. CPI inflation rate for the 12-month period following the experiment (December 2009 through December 2010). The correlation between this error and the MAE from the experiment is 0.328 , which is somewhat weaker but still statistically significant (p-value 0.00 ). These positive correlations provide some reassurance that forecasting performance in the simulated economy is indicative of inflation-forecasting ability in the real world.

\footnotetext{
30 These figures depict truncated distributions, from which extreme values have been excluded, as described in the preceding footnote.
} 


\section{b. Real-world inflation and economic literacy}

Table 8 shows mean inflation perceptions and forecasts among our subjects, broken down by demographic category. Variation in perceptions of past inflation agree broadly with results from previous surveys: women perceived higher inflation than men, non-whites perceived higher inflation than whites (averaging across non-white groups), and perceptions appear to decrease (though not systematically) with income and educational attainment. However, demographic patterns in the U.S. inflation forecasts are much harder to discern, especially in the case of one-year-ahead forecasts.

In multivariate analysis of the accuracy of perceptions and expectations of U.S. inflation, we find that few of the factors considered in Table 8 have significant effects, regardless of whether the estimates controlled for economic literacy, while economic literacy itself is an important factor. Concerning prior (past five years) U.S. inflation (Table 9, columns 1 and 2), economic literacy exerts a significant negative effect on the absolute estimation error, such that each 10percentage-point increase in the score lowers the error by roughly 0.59 percentage point. ${ }^{31}$ (A linear model offers a better fit than a quadratic model in this case.) In addition, when economic literacy is added to the model, the positive effect of female gender on the error becomes only marginally significant (p-value 0.07), and the adjusted R-squared value more than doubles (from 0.05 to 0.13 ). ${ }^{32}$ Regarding absolute forecast errors for U.S. inflation one year forward (Table 9, columns 3 and 4), none of the demographic or socioeconomic factors matter (at the 5 percent level or better), whether economic literacy is included or not. Again, literacy exerts a significant negative effect on the forecast error, although the effect is weaker than that just described for accuracy of past inflation. ${ }^{33}$ For the five-year-ahead inflation forecasts, we analyze levels rather than errors, lacking a true benchmark value. As seen in the Table 9 (columns 5 and 6), higher literacy scores are associated with lower inflation forecasts, but the effect is not

\footnotetext{
31 Our literacy measure appears to trump the effect of the economics course dummy, which is significant when literacy is excluded from the model but not when both are included (results shown are for model that excludes economics course).

32 Results are OLS estimates. Tests for heteroscedasticity did not reject the null of homoscedasticity.

${ }^{33}$ In this regression, we excluded an observation in which the forecast was equal to 50 percent, because inclusion of this outlier distorted regression results significantly. The next-highest forecast value after 50 was 15.
} 
statistically significant. Taken together, these results suggest that economic literacy contributes to more-accurate inflation perceptions and forecasts in the real world and therefore bolsters the relevance of our findings in the experimental setting.

\section{c. Analysis of free-response questions}

In response to the open-ended question asking what additional information they would have liked to help make their inflation forecasts, the most popular type of response involved a request for information about the prices of specific goods, such as houses, various food items, cars, gold, electricity, and various other items.

Considering the responses overall, more than a third of subjects either requested data similar to our included choices (such as specific prices and more about inflation) or requested no additional information. These responses indicate that our menu of choices included at least some of the types of information people refer to when forming inflation expectations in a realworld context. The request for "more background knowledge" rather than specific other information suggests that subjects believed the given information was relevant but they did not know how to best use it to make an inflation forecast. In addition, the overall seriousness of the responses indicates subjects took the experiment itself seriously.

\section{Summary and Discussion}

In data from a new experiment designed to elicit subjects' prior tendencies and beliefs with respect to the formation of inflation expectations, we find strong associations between our measure of economic-and-financial literacy and the behaviors of interest. In the simulatedeconomy forecasting exercises, more-literate subjects displayed lower (signed) errors on average as well as lower absolute errors. The effects of economic literacy are highly significant and are robust to an extensive list of demographic and socioeconomic controls, including general educational attainment-both own and mother's - as well as household income, age, gender, and race. Therefore, we can be fairly certain that the associations between economic literacy and inflation expectations do not arise spuriously. Economic literacy is also associated 
with more-accurate perceptions and predictions of actual U.S. inflation, findings that corroborate those observed for forecasts in the simulated economy.

We identify two channels through which economic literacy contributed to greater forecasting accuracy in our experiment. As illustrated by their greater success in the exogenous-information exercises, more- literate subjects were better able to make use of given data to come up with a reasonable inflation forecast. As illustrated by their greater success in the endogenousinformation exercises, together with the analysis of information selection, more-literate subjects were also better at selecting relevant information, such as recent inflation data, in the course of making a forecast. Both selection and use of information could have influenced success in the endogenous-information exercises, and consistent with this fact we find that economic literacy had a greater impact on performance (measured by mean absolute errors within-subject) in the endogenous exercises than in the exogenous set. Finally, performance across all exercises cannot be reduced to mere numeracy. Both financial and monetary literacy contribute independently to forecasting success.

Our findings imply that variation in inflation-forecasting behavior observed in previous experiments - which have in general provided all of their subjects with the same information sets, rather than offering a choice of information - while significant, is likely to be significantly diminished relative to real-world variation in such behavior. Macroeconomic models also generally fail to allow heterogeneity in the nature of data employed in making economic forecasts. Those models that do admit heterogeneity in expectation formation, such Mankiw and Reis (2002), Carroll (2003), Malmendier and Nagel (2009), and others, tend to posit that agents hold similar conceptual models of inflation and yet may update their data at different frequencies or apply different learning rules in updating their parameter estimates.

Demographic and socioeconomic factors influence behavior in some dimensions, although by less than we might have expected based on results of previous surveys, and many effects are not robust. For example, while women give higher estimates of past U.S. inflation, the difference can be accounted for by gender differences in economic literacy. African-Americans have higher mean errors in forecasting inflation in the simulated environment (but not when 
estimating past U.S. inflation), indicating stronger positive inflation bias, and higher absolute errors as well, but the effects become insignificant after controlling for economic literacy. These findings suggest that demographic variation in inflation expectations observed in various survey data may be partly attributable to differences in economic literacy across groups.

Taken together, our results suggest that improved economic education, including possibly the education provided by central bank communications, can promote greater uniformity and accuracy in inflation expectations. In particular, results comparing performance between the exogenous and endogenous exercises suggest that consumers' inflation forecasts might be improved simply by teaching them to focus on recent aggregate inflation data rather than on specific prices. For such education to be effective, however, subjects would first need to understand the concept of aggregate inflation and how to access information on the CPI or similar measures, and neither prerequisite should be taken for granted for the average consumer. 


\section{References}

Adam, Klaus. 2007. "Experimental Evidence on the Persistence of Output and Inflation." Economic Journal 117: 603-636.

Arifovic, Jasmina, and Thomas J. Sargent. 2003. “Laboratory Experiments with an Expectational Phillips Curve." in David E. Altig and Bruce D. Smith (eds.), Evolution and Procedures in Central Banking. Cambridge University Press, Cambridge.

Armantier, Olivier, Wandi Bruine de Bruin, Giorgio Topa, Wilbert van der Klaauw, and Basit Zafar. 2011. "Inflation Expectations and Behavior: Do Survey Respondents Act on their Beliefs?" Federal Reserve Bank of New York, Staff Report no. 509, August 2011.

Becker, Otwin, Johannes Leitner, and Ulrike Leopold-Wildburger. 2009. “Expectation Formation and Regime Switches." Experimental Economics 12: 350-364.

Beckman, Steven R., and David Downs. 1997. “Forecasters as Imperfect Information Processors: Experimental and Survey Evidence." Journal of Economic Behavior E Organization 32: 89100.

Bergmann, Barbara 1988. "An experiment on the formation of expectations." Journal of Economic Behavior and Organization 9: 137-151.

Bernanke, Ben S. 2007. "Inflation Expectations and Inflation Forecasting." Speech delivered at the National Bureau of Economic Research, Cambridge, Massachusetts, July 10, 2007. http://www.federalreserve.gov/newsevents/speech/bernanke20070710a.htm

Bernasconi, Michele, and Oliver Kirchkamp. 2000. "Why do monetary policies matter? An experimental study of saving and inflation in an overlapping generations model." Journal of Monetary Economics 46(2): 315-343.

Blanchflower, David G., and Conall Mac Coille. 2009. "The formation of inflation expectations: an empirical analysis for the UK." NBER working paper w15388.

Blomqvist, Hans C. 1989. “The 'Rationality' of Expectations: an Experimental Approach.” Journal of Economic Psychology 10: 275-299.

Bloomfield, Robert, and Jeffrey Hales. 2002. "Predicting the Next Step of a Random Walk: Experimental Evidence of Regime-Shifting Beliefs." Journal of Financial Economics 65: 397-414. 
Bolle, Friedel 1988a. "Testing for rational expectations in experimental predictions." in Applied Behavioural Economics, vol. 1 (ed. Shlomo Maital). New York: New York University Press.

Bolle, Friedel 1988b. "Learning to make good predictions in time series." in Bounded Rational Behavior in Experimental Games and Markets (Reinhard Tietz, Willi Albers and Reinhard Selten, eds.). Berlin: Springer-Verlag.

Bruine de Bruin, Wandi, Wilbert Vanderklaauw, Julie S. Downs, Baruch Fischhoff, Giorgio Topa, and Olivier Armantier. 2010. "Expectations of inflation: The role of financial literacy and demographic variables." Journal of Consumer Affairs 44: 381-402.

Bryan, Michael F., and Guhan Venkatu. 2001a. "The curiously different inflation perspectives of men and women." Economic Commentary, Federal Reserve Bank of Cleveland, November 2001.

Bryan, Michael F., and Guhan Venkatu. 2001b. "The demographics of inflation opinion surveys." Economic Commentary, Federal Reserve Bank of Cleveland, October 2001.

Carroll, Christopher D. 2003. Macroeconomic Expectations of Households and Professional Forecasters. Quarterly Journal of Economics 118(1): 269-298.

Dudley, William C. 2009. "The Economic Outlook and the Fed's Balance Sheet: The Issue of 'How' versus 'When'." Speech, July 29, 2009. Available at http://newyorkfed.org/newsevents/speeches/2009/dud090729.html

Duffy, David, and Peter D. Lunn. 2009. "The misperception of inflation by Irish consumers." The Economic and Social Review 40(2): 139-163.

Dwyer, Gerald P., Arlington W. Williams, Raymond C. Battalio, and Timothy I . Mason. 1993. "Tests of Rational Expectations in a Stark Setting." The Economic Journal 103 (418): 586601.

Federal Open Market Committee, minutes of meeting of January 27-28, 2009 and minutes of meeting of November 2-3 2010. Available at http://www.federalreserve.gov/monetarypolicy/fomccalendars.htm

Heit, Evan 2000. "Properties of Inductive Reasoning." Psychonomic Bulletin E Review 7(4): 569592.

Hey, John D. 1994. “Expectations formation: Rational or adaptive or ...?” Journal of Economic Behavior and Organization 25: 329-349. 
Hobijn, Bart, Giorgio Topa, Kristin Mayer, and Carter Stennis. 2008. “Whose Inflation Is It? Household Level vs. Aggregate Measures of Inflation." Manuscript. Federal Reserve Bank of New York.

Jonung, Lars. 1981. "Perceived and Expected rates of Inflation in Sweden." The American Economic Review 71 (5): 961--968.

Jump\$tart Coalition Survey of Personal Financial Literacy Among Students, 2008. http://www.jumpstart.org/survey.html

Kershoff, George. 2000. “Conducting inflation expectation surveys in South Africa." Bureau for Economic Research.

Lawrence, Michael, Paul Goodwin, Marcus O'Conner, and Dilek Onkal. 2006. “Judgemental Forecasting: A review of progress over the last 25 years," International Journal of Forecasting 22: 493-518.

Leung, Christina. 2009. "The demographics of household inflation perceptions and expectations." Reserve Bank of New Zealand: Bulletin, Vol. 72, No. 2, June 2009.

Malmendier, Ulrike, and Stefan Nagel. 2009. "Learning from Inflation Experiences." Manuscript. Available at http://faculty-gsb.stanford.edu/nagel/pdfs/InflExp.pdf

Mankiw, N. Gregory, and Ricardo Reis. 2002. “Sticky Information Versus Sticky Prices: A Proposal to Replace the New Keynesian Phillips Curve." Quarterly Journal of Economics 117(4): 1295-1328.

Marimon, Ramon, and Shyam Sunder. 1995. "Does a constant money growth rule help stabilize inflation? Experimental evidence." Carnegie-Rochester Conference Series on Public Policy 43(1): 111-156.

Peterson, Steven P., and Robert J. Reilly. 1991. "The Rationality of Expectations: The Blomqvist Experiment Reconsidered." Journal of Economic Psychology 12: 527-533.

Pfajfar, Damjan, and Emiliano Santoro. 2008. "Asymmetries in Inflation Expectation Formation Across Demographic Groups." Cambridge Working Papers in Economics 0824, Faculty of Economics, University of Cambridge.

Pfajfar, Damjan, and Blaz Zakelj. 2009. “Experimental Evidence on Inflation Expectation Formation." Discussion paper 2009-07, Tilburg University, Center for Economic Research. 
Roetheli, Tobias F., 2011. "Pattern-Based Expectations: International Experimental Evidence and Applications in Financial Economics." Review of Economics and Statistics 93(4): 1319--1330

Souleles, Nicholas S. 2004. "Expectations, Heterogeneous Forecast Errors, and Consumption: Micro Evidence from the Michigan Consumer Sentiment Surveys." Journal of Money, Credit and Banking 36(1): 39-72.

Van Rooij, Maarten, Annamaria Lusardi, and Rob Alessie. 2007." Financial Literacy and Stock Market Participation." NBER working paper 13565. 
Table 1: Sample characteristics

\begin{tabular}{lr}
\hline Age & 28.533 \\
Female & 0.610 \\
White & 0.599 \\
Black & 0.109 \\
Hispanic & 0.022 \\
Asian & 0.139 \\
Other Race & 0.044 \\
Multiracial & 0.088 \\
Not US-Born & 0.175 \\
Economics Course & 0.533 \\
Income $\leq \$ 39,999$ & 0.453 \\
Income $\$ 40,000-\$ 79,999$ & 0.190 \\
Income $\$ 80,000-\$ 149,999$ & 0.190 \\
Income $\geq \$ 150,000$ & 0.153 \\
HS Diploma or less & 0.066 \\
Some College & 0.394 \\
Bachelor's Deg. & 0.387 \\
Advanced Deg. & 0.153 \\
Mother HS Diploma & 0.153 \\
Mother Some College & 0.080 \\
Mother Bachelor's Deg. & 0.343 \\
Mother Advanced Deg. & 0.336 \\
\hline N=137 Note: The mother's education variables do not sum to one because of nonresponse
\end{tabular}

$\mathrm{N}=137$ Note: The mother's education variables do not sum to one because of nonresponse

Table 2: Literacy score statistics

\begin{tabular}{ll}
\hline Mean & 0.663 \\
Std. Deviation & 0.188 \\
Median & 0.690 \\
Minimum & 0.130 \\
Maximum & 1.000 \\
Cronbach's $\alpha$ & 0.740 \\
\hline
\end{tabular}


Table 3: Determinants of economic literacy score

\begin{tabular}{|c|c|c|}
\hline Female & $\begin{array}{c}-0.084^{* *} \\
(0.034)\end{array}$ & $\begin{array}{c}-0.070^{* *} \\
(0.031)\end{array}$ \\
\hline Age 22-24 & $\begin{array}{l}-0.036 \\
(0.057)\end{array}$ & $\begin{array}{l}-0.023 \\
(0.054)\end{array}$ \\
\hline Age 25-31 & $\begin{array}{l}-0.088 \\
(0.063)\end{array}$ & $\begin{array}{l}-0.065 \\
(0.059)\end{array}$ \\
\hline Age $\geq 32$ & $\begin{array}{l}-0.105^{*} \\
(0.056)\end{array}$ & $\begin{array}{l}-0.074 \\
(0.052)\end{array}$ \\
\hline Black & $\begin{array}{c}-0.108^{* *} \\
(0.051)\end{array}$ & $\begin{array}{c}-0.107^{* *} \\
(0.048)\end{array}$ \\
\hline Hispanic & $\begin{array}{l}-0.001 \\
(0.108)\end{array}$ & $\begin{array}{c}0.076 \\
(0.102)\end{array}$ \\
\hline Asian & $\begin{array}{c}0.005 \\
(0.053)\end{array}$ & $\begin{array}{l}-0.005 \\
(0.050)\end{array}$ \\
\hline Multiracial & $\begin{array}{c}0.018 \\
(0.058)\end{array}$ & $\begin{array}{l}0.000 \\
(0.054)\end{array}$ \\
\hline Other Race & $\begin{array}{c}-0.144^{*} \\
(0.080)\end{array}$ & $\begin{array}{l}-0.110 \\
(0.075)\end{array}$ \\
\hline Not US-Born & $\begin{array}{c}0.060 \\
(0.046)\end{array}$ & $\begin{array}{l}0.061 \\
(0.043)\end{array}$ \\
\hline Some College & $\begin{array}{l}0.120^{*} \\
(0.070)\end{array}$ & $\begin{array}{l}0.123^{*} \\
(0.065)\end{array}$ \\
\hline Bachelor's Deg. & $\begin{array}{l}0.185^{* *} \\
(0.073)\end{array}$ & $\begin{array}{c}0.147^{* *} \\
(0.068)\end{array}$ \\
\hline Advanced Deg. & $\begin{array}{c}0.272^{* * * *} \\
(0.081)\end{array}$ & $\begin{array}{c}0.245^{* * *} \\
(0.076)\end{array}$ \\
\hline Mother Some College & $\begin{array}{c}0.051 \\
(0.063)\end{array}$ & $\begin{array}{c}0.090 \\
(0.060)\end{array}$ \\
\hline Mother Bachelor's Deg. & $\begin{array}{c}0.041 \\
(0.045)\end{array}$ & $\begin{array}{c}0.028 \\
(0.042)\end{array}$ \\
\hline Mother Advanced Deg. & $\begin{array}{c}0.061 \\
(0.046)\end{array}$ & $\begin{array}{c}0.052 \\
(0.043)\end{array}$ \\
\hline Income $\$ 40,000-\$ 79,999$ & $\begin{array}{c}0.012 \\
(0.044)\end{array}$ & $\begin{array}{l}-0.009 \\
(0.041)\end{array}$ \\
\hline Income $\$ 80,000-\$ 149,999$ & $\begin{array}{c}0.001 \\
(0.047)\end{array}$ & $\begin{array}{l}-0.023 \\
(0.044)\end{array}$ \\
\hline Income $\geq \$ 150,000$ & $\begin{array}{l}-0.003 \\
(0.052)\end{array}$ & $\begin{array}{l}-0.007 \\
(0.048)\end{array}$ \\
\hline Economics Course & & $\begin{array}{c}0.134^{* * *} \\
(0.031)\end{array}$ \\
\hline Constant & $\begin{array}{c}0.571^{* * *} \\
(0.075)\end{array}$ & $\begin{array}{c}0.506^{* * *} \\
(0.071)\end{array}$ \\
\hline Adjusted $R^{2}$ & 0.138 & 0.249 \\
\hline
\end{tabular}


Table 4a: Determinants of simulated-economy forecasting performance

\begin{tabular}{|c|c|c|c|c|}
\hline & Mean Error & Mean Error & Mean Abs. Error & Mean Abs. Error \\
\hline Literacy Score & & $\begin{array}{c}-11.954^{* * *} \\
(3.151)\end{array}$ & & $\begin{array}{c}-8.407 * * * \\
(1.814)\end{array}$ \\
\hline Lit. Score ${ }^{2}$ & & $\begin{array}{c}8.444^{* * *} \\
(2.256)\end{array}$ & & $\begin{array}{c}5.217^{* * * *} \\
(1.287)\end{array}$ \\
\hline Age $22-24$ & $\begin{array}{c}0.209 \\
(0.416)\end{array}$ & $\begin{array}{c}0.008 \\
(0.323)\end{array}$ & $\begin{array}{c}0.290 \\
(0.268)\end{array}$ & $\begin{array}{c}0.128 \\
(0.181)\end{array}$ \\
\hline Age $25-31$ & $\begin{array}{c}0.510 \\
(0.380)\end{array}$ & $\begin{array}{c}0.186 \\
(0.281)\end{array}$ & $\begin{array}{c}0.328 \\
(0.280)\end{array}$ & $\begin{array}{c}0.053 \\
(0.192)\end{array}$ \\
\hline Age $\geq 32$ & $\begin{array}{l}0.593^{*} \\
(0.325)\end{array}$ & $\begin{array}{c}0.080 \\
(0.295)\end{array}$ & $\begin{array}{c}0.676^{* * *} \\
(0.208)\end{array}$ & $\begin{array}{c}0.250 \\
(0.159)\end{array}$ \\
\hline Female & $\begin{array}{c}0.102 \\
(0.193)\end{array}$ & $\begin{array}{c}0.037 \\
(0.177)\end{array}$ & $\begin{array}{c}0.097 \\
(0.127)\end{array}$ & $\begin{array}{l}-0.027 \\
(0.101)\end{array}$ \\
\hline Not US-Born & $\begin{array}{c}0.286 \\
(0.232)\end{array}$ & $\begin{array}{l}0.391^{*} \\
(0.221)\end{array}$ & $\begin{array}{c}0.047 \\
(0.179)\end{array}$ & $\begin{array}{c}0.176 \\
(0.154)\end{array}$ \\
\hline Hispanic & $\begin{array}{c}1.100 \\
(1.703)\end{array}$ & $\begin{array}{l}1.143 \\
(1.637)\end{array}$ & $\begin{array}{c}1.971 \\
(1.195)\end{array}$ & $\begin{array}{l}1.991^{* *} \\
(0.983)\end{array}$ \\
\hline Black & $\begin{array}{c}0.747^{* *} \\
(0.299)\end{array}$ & $\begin{array}{c}0.371 \\
(0.243)\end{array}$ & $\begin{array}{l}0.528^{* *} \\
(0.263)\end{array}$ & $\begin{array}{c}0.182 \\
(0.190)\end{array}$ \\
\hline Asian & $\begin{array}{c}0.178 \\
(0.172)\end{array}$ & $\begin{array}{c}0.252 \\
(0.157)\end{array}$ & $\begin{array}{c}0.218 \\
(0.134)\end{array}$ & $\begin{array}{c}0.264^{* *} \\
(0.124)\end{array}$ \\
\hline Other Race & $\begin{array}{c}0.449 \\
(0.519)\end{array}$ & $\begin{array}{c}0.322 \\
(0.388)\end{array}$ & $\begin{array}{c}0.226 \\
(0.459)\end{array}$ & $\begin{array}{c}0.008 \\
(0.303)\end{array}$ \\
\hline Multiracial & $\begin{array}{l}-0.103 \\
(0.274)\end{array}$ & $\begin{array}{l}-0.137 \\
(0.256)\end{array}$ & $\begin{array}{l}-0.139 \\
(0.162)\end{array}$ & $\begin{array}{l}-0.140 \\
(0.127)\end{array}$ \\
\hline Income $\$ 40,000-\$ 79,999$ & $\begin{array}{c}0.222 \\
(0.245)\end{array}$ & $\begin{array}{c}0.287 \\
(0.214)\end{array}$ & $\begin{array}{l}-0.078 \\
(0.150)\end{array}$ & $\begin{array}{l}-0.024 \\
(0.122)\end{array}$ \\
\hline Income $\$ 80,000-\$ 149,999$ & $\begin{array}{c}0.080 \\
(0.257)\end{array}$ & $\begin{array}{c}0.003 \\
(0.204)\end{array}$ & $\begin{array}{l}-0.115 \\
(0.164)\end{array}$ & $\begin{array}{l}-0.157 \\
(0.126)\end{array}$ \\
\hline Income $\geq \$ 150,000$ & $\begin{array}{c}0.010 \\
(0.236)\end{array}$ & $\begin{array}{c}0.139 \\
(0.219)\end{array}$ & $\begin{array}{l}-0.276 \\
(0.177)\end{array}$ & $\begin{array}{l}-0.195 \\
(0.161)\end{array}$ \\
\hline Some College & $\begin{array}{c}0.510 \\
(0.507)\end{array}$ & $\begin{array}{c}0.859 \\
(0.549)\end{array}$ & $\begin{array}{c}0.241 \\
(0.343)\end{array}$ & $\begin{array}{c}0.573^{* *} \\
(0.262)\end{array}$ \\
\hline Bachelor's Deg. & $\begin{array}{c}0.468 \\
(0.610)\end{array}$ & $\begin{array}{c}0.760 \\
(0.582)\end{array}$ & $\begin{array}{c}0.114 \\
(0.438)\end{array}$ & $\begin{array}{c}0.362 \\
(0.283)\end{array}$ \\
\hline Advanced Deg. & $\begin{array}{l}-0.010 \\
(0.531)\end{array}$ & $\begin{array}{c}0.751 \\
(0.574)\end{array}$ & $\begin{array}{l}-0.380 \\
(0.369)\end{array}$ & $\begin{array}{c}0.361 \\
(0.277)\end{array}$ \\
\hline Mother Some College & $\begin{array}{l}-0.337 \\
(0.367)\end{array}$ & $\begin{array}{l}-0.131 \\
(0.316)\end{array}$ & $\begin{array}{l}-0.397 \\
(0.286)\end{array}$ & $\begin{array}{l}-0.148 \\
(0.171)\end{array}$ \\
\hline Mother Bachelor's Deg. & $\begin{array}{c}0.033 \\
(0.298)\end{array}$ & $\begin{array}{c}0.070 \\
(0.258)\end{array}$ & $\begin{array}{l}-0.233 \\
(0.178)\end{array}$ & $\begin{array}{l}-0.164 \\
(0.147)\end{array}$ \\
\hline Mother Advanced Deg. & $\begin{array}{l}-0.046 \\
(0.286)\end{array}$ & $\begin{array}{c}0.059 \\
(0.245)\end{array}$ & $\begin{array}{c}-0.350^{* *} \\
(0.176)\end{array}$ & $\begin{array}{l}-0.218 \\
(0.140)\end{array}$ \\
\hline Constant & $\begin{array}{l}-0.123 \\
(0.510)\end{array}$ & $\begin{array}{c}3.576^{* * *} \\
(1.243)\end{array}$ & $\begin{array}{c}1.680 * * * \\
(0.342)\end{array}$ & $\begin{array}{c}4.542^{* * *} \\
(0.606)\end{array}$ \\
\hline $\begin{array}{l}\text { Adjusted } R^{2} \\
N\end{array}$ & $\begin{array}{c}-0.011 \\
135\end{array}$ & $\begin{array}{c}0.146 \\
135\end{array}$ & $\begin{array}{c}0.237 \\
135\end{array}$ & $\begin{array}{c}0.490 \\
135\end{array}$ \\
\hline
\end{tabular}


Table 4b: Determinants of simulated-economy forecasting performance, standardized coefficients

\begin{tabular}{|c|c|c|c|c|}
\hline & Mean Error & Mean Error & Mean Abs. Error & Mean Abs. Error \\
\hline Literacy Score & & $-2.180 * * *$ & & $-2.066^{* * *}$ \\
\hline Lit. Score ${ }^{2}$ & & $1.930 * * *$ & & $1.607^{* * *}$ \\
\hline Age $22-24$ & 0.083 & 0.003 & 0.156 & 0.069 \\
\hline Age 25-31 & 0.213 & 0.078 & 0.185 & 0.030 \\
\hline Age $\geq 32$ & $0.250^{*}$ & 0.034 & $0.385 * * *$ & 0.142 \\
\hline Female & 0.049 & 0.018 & 0.063 & -0.017 \\
\hline Not US-Born & 0.107 & $0.147^{*}$ & 0.024 & 0.089 \\
\hline Hispanic & 0.159 & 0.166 & 0.385 & $0.389 * *$ \\
\hline Black & $0.224^{* *}$ & 0.111 & $0.213^{* *}$ & 0.074 \\
\hline Asian & 0.061 & 0.086 & 0.101 & $0.122^{* *}$ \\
\hline Other Race & 0.091 & 0.065 & 0.062 & 0.002 \\
\hline Multiracial & -0.029 & -0.038 & -0.052 & -0.053 \\
\hline Income $\$ 40,000-\$ 79,999$ & 0.086 & 0.111 & -0.041 & -0.012 \\
\hline Income $\$ 80,000-\$ 149,999$ & 0.031 & 0.001 & -0.060 & -0.082 \\
\hline Income $\geq \$ 150,000$ & 0.004 & 0.049 & -0.133 & -0.093 \\
\hline Some College & 0.245 & 0.412 & 0.156 & $0.371^{* *}$ \\
\hline Bachelor's Deg. & 0.225 & 0.365 & 0.074 & 0.234 \\
\hline Advanced Deg. & -0.003 & 0.267 & -0.182 & 0.173 \\
\hline Mother Some College & -0.164 & -0.064 & -0.261 & -0.098 \\
\hline Mother Bachelor's Deg. & 0.015 & 0.033 & -0.146 & -0.103 \\
\hline Mother Advanced Deg. & -0.021 & 0.027 & $-0.220 * *$ & -0.137 \\
\hline Adjusted $\mathrm{R}^{2}$ & -0.011 & 0.146 & 0.237 & 0.490 \\
\hline $\mathrm{N}$ & 135 & 135 & 135 & 135 \\
\hline
\end{tabular}


Table 5: Determinants of mean absolute errors: Exogenous vs. endogenous exercises

\begin{tabular}{|c|c|c|}
\hline & Exogenous & Endogenous \\
\hline Literacy Score & $\begin{array}{c}-9.492^{* * *} \\
(1.953)\end{array}$ & $\begin{array}{c}-13.278^{* * *} \\
(3.088)\end{array}$ \\
\hline Lit. Score ${ }^{2}$ & $\begin{array}{c}5.970^{* * *} \\
(1.523)\end{array}$ & $\begin{array}{c}8.281^{* * *} \\
(2.408)\end{array}$ \\
\hline Female & $\begin{array}{c}0.129 \\
(0.136)\end{array}$ & $\begin{array}{l}-0.240 \\
(0.215)\end{array}$ \\
\hline Age $22-24$ & $\begin{array}{c}0.073 \\
(0.228)\end{array}$ & $\begin{array}{c}0.042 \\
(0.361)\end{array}$ \\
\hline Age $25-31$ & $\begin{array}{l}-0.102 \\
(0.252)\end{array}$ & $\begin{array}{c}0.323 \\
(0.398)\end{array}$ \\
\hline Age $\geq 32$ & $\begin{array}{c}0.077 \\
(0.237)\end{array}$ & $\begin{array}{c}0.537 \\
(0.375)\end{array}$ \\
\hline Black & $\begin{array}{c}0.042 \\
(0.215)\end{array}$ & $\begin{array}{c}0.704^{* *} \\
(0.341)\end{array}$ \\
\hline Hispanic & $\begin{array}{c}1.480^{* * *} \\
(0.423)\end{array}$ & $\begin{array}{c}2.589^{* * *} \\
(0.669)\end{array}$ \\
\hline Asian & $\begin{array}{c}0.234 \\
(0.211)\end{array}$ & $\begin{array}{l}0.655^{*} \\
(0.333)\end{array}$ \\
\hline Multiracial & $\begin{array}{l}-0.074 \\
(0.228)\end{array}$ & $\begin{array}{l}-0.253 \\
(0.361)\end{array}$ \\
\hline Other Race & $\begin{array}{l}-0.241 \\
(0.318)\end{array}$ & $\begin{array}{c}0.086 \\
(0.502)\end{array}$ \\
\hline Not US-Born & $\begin{array}{c}0.236 \\
(0.184)\end{array}$ & $\begin{array}{c}0.382 \\
(0.291)\end{array}$ \\
\hline Some College & $\begin{array}{c}0.806^{* * *} \\
(0.292)\end{array}$ & $\begin{array}{c}0.916^{* *} \\
(0.462)\end{array}$ \\
\hline Bachelor's Deg. & $\begin{array}{c}0.423 \\
(0.311)\end{array}$ & $\begin{array}{c}0.635 \\
(0.491)\end{array}$ \\
\hline Advanced Deg. & $\begin{array}{l}0.625^{*} \\
(0.355)\end{array}$ & $\begin{array}{c}0.592 \\
(0.562)\end{array}$ \\
\hline Mother Some College & $\begin{array}{c}0.061 \\
(0.256)\end{array}$ & $\begin{array}{l}-0.086 \\
(0.405)\end{array}$ \\
\hline Mother Bachelor's Deg. & $\begin{array}{l}-0.222 \\
(0.179)\end{array}$ & $\begin{array}{l}-0.062 \\
(0.283)\end{array}$ \\
\hline Mother Advanced Deg. & $\begin{array}{l}-0.188 \\
(0.185)\end{array}$ & $\begin{array}{l}-0.289 \\
(0.292)\end{array}$ \\
\hline Income $\$ 40,000-\$ 79,999$ & $\begin{array}{l}-0.211 \\
(0.175)\end{array}$ & $\begin{array}{c}0.259 \\
(0.277)\end{array}$ \\
\hline Income $\$ 80,000-\$ 149,999$ & $\begin{array}{l}-0.272 \\
(0.188)\end{array}$ & $\begin{array}{l}-0.155 \\
(0.297)\end{array}$ \\
\hline Income $\geq \$ 150,000$ & $\begin{array}{l}-0.197 \\
(0.205)\end{array}$ & $\begin{array}{l}-0.244 \\
(0.324)\end{array}$ \\
\hline Constant & $\begin{array}{c}4.887^{* * *} \\
(0.649)\end{array}$ & $\begin{array}{c}5.774^{* * *} \\
(1.026)\end{array}$ \\
\hline Adjusted $\mathrm{R}^{2}$ & 0.444 & 0.458 \\
\hline $\mathrm{N}$ & 135 & 135 \\
\hline
\end{tabular}

Standard errors reported in parentheses.

*** indicates significance at the one-percent level; ${ }^{* *}$ indicates significance at the five-percent level; * indicates significance at the ten-percent level. 
Table 6: Forecast accuracy and components of economic literacy

\begin{tabular}{|c|c|}
\hline & Mean abs. error \\
\hline Monetary literacy & $\begin{array}{c}-3.971^{* * *} \\
(1.222)\end{array}$ \\
\hline Monetary lit. $^{2}$ & $\begin{array}{c}2.746^{* * * *} \\
(0.995)\end{array}$ \\
\hline Financial literacy & $\begin{array}{c}-4.611^{* * *} \\
(1.375)\end{array}$ \\
\hline Financial lit. $^{2}$ & $\begin{array}{c}2.541^{* *} \\
(1.061)\end{array}$ \\
\hline Numeracy & $\begin{array}{l}-1.314 \\
(0.836)\end{array}$ \\
\hline Numeracy $^{2}$ & $\begin{array}{c}0.844 \\
(0.687)\end{array}$ \\
\hline Female & $\begin{array}{l}-0.065 \\
(0.131)\end{array}$ \\
\hline Age $22-24$ & $\begin{array}{c}0.124 \\
(0.226)\end{array}$ \\
\hline Age $25-31$ & $\begin{array}{l}0.214 \\
(0.244)\end{array}$ \\
\hline Age $\geq 32$ & $\begin{array}{l}0.393^{*} \\
(0.233)\end{array}$ \\
\hline Black & $\begin{array}{c}0.344 \\
(0.212)\end{array}$ \\
\hline Hispanic & $\begin{array}{c}2.101^{* * *} \\
(0.402)\end{array}$ \\
\hline Asian & $\begin{array}{l}0.381^{*} \\
(0.202)\end{array}$ \\
\hline Multiracial & $\begin{array}{l}-0.182 \\
(0.218)\end{array}$ \\
\hline Other Race & $\begin{array}{l}-0.061 \\
(0.305)\end{array}$ \\
\hline Not US-Born & $\begin{array}{c}0.261 \\
(0.175)\end{array}$ \\
\hline Some College & $\begin{array}{c}0.781^{* * *} \\
(0.276)\end{array}$ \\
\hline Bachelor's Deg. & $\begin{array}{c}0.384 \\
(0.293)\end{array}$ \\
\hline Advanced Deg. & $\begin{array}{c}0.460 \\
(0.334)\end{array}$ \\
\hline Mother Some College & $\begin{array}{l}-0.106 \\
(0.247)\end{array}$ \\
\hline Mother Bachelor's Deg. & $\begin{array}{l}-0.179 \\
(0.173)\end{array}$ \\
\hline Mother Advanced Deg. & $\begin{array}{l}-0.227 \\
(0.178)\end{array}$ \\
\hline Income $\$ 40,000-\$ 79,999$ & $\begin{array}{l}-0.001 \\
(0.169)\end{array}$ \\
\hline Income $\$ 80,000-\$ 149,999$ & $\begin{array}{l}-0.147 \\
(0.177)\end{array}$ \\
\hline Income $\$ 150,000$ or more & $\begin{array}{l}-0.208 \\
(0.201)\end{array}$ \\
\hline Constant & $\begin{array}{c}4.770^{* * * *} \\
(0.570)\end{array}$ \\
\hline $\begin{array}{l}\text { Adjusted } \mathrm{R}^{2} \\
\mathrm{~N}\end{array}$ & $\begin{array}{c}0.491 \\
135\end{array}$ \\
\hline
\end{tabular}


Table 7: Determinants of per-subject inflation-choice rate

\begin{tabular}{|c|c|c|}
\hline Literacy Score & & $\begin{array}{c}3.095^{* * *} \\
(0.504)\end{array}$ \\
\hline Lit. Score ${ }^{2}$ & & $\begin{array}{c}-2.091^{* * *} \\
(0.394)\end{array}$ \\
\hline Age 22-24 & $\begin{array}{c}-0.185^{* * *} \\
(0.070)\end{array}$ & $\begin{array}{c}-0.132^{* *} \\
(0.059)\end{array}$ \\
\hline Age $25-31$ & $\begin{array}{c}-0.284^{* * *} \\
(0.077)\end{array}$ & $\begin{array}{c}-0.192 * * * \\
(0.065)\end{array}$ \\
\hline Age $\geq 32$ & $\begin{array}{c}-0.351^{* * * *} \\
(0.069)\end{array}$ & $\begin{array}{c}-0.206^{* * *} \\
(0.061)\end{array}$ \\
\hline Female & $\begin{array}{l}-0.040 \\
(0.041)\end{array}$ & $\begin{array}{l}-0.011 \\
(0.035)\end{array}$ \\
\hline Not US-Born & $\begin{array}{c}0.016 \\
(0.057)\end{array}$ & $\begin{array}{l}-0.017 \\
(0.048)\end{array}$ \\
\hline Hispanic & $\begin{array}{c}-0.415^{* * *} \\
(0.131)\end{array}$ & $\begin{array}{c}-0.426^{* * *} \\
(0.109)\end{array}$ \\
\hline Black & $\begin{array}{c}-0.118^{*} \\
(0.065)\end{array}$ & $\begin{array}{l}-0.013 \\
(0.056)\end{array}$ \\
\hline Asian & $\begin{array}{l}-0.098 \\
(0.065)\end{array}$ & $\begin{array}{c}-0.117^{* *} \\
(0.055)\end{array}$ \\
\hline Multiracial & $\begin{array}{c}0.074 \\
(0.071)\end{array}$ & $\begin{array}{c}0.081 \\
(0.059)\end{array}$ \\
\hline Other Race & $\begin{array}{l}-0.158 \\
(0.097)\end{array}$ & $\begin{array}{l}-0.101 \\
(0.082)\end{array}$ \\
\hline Income $\$ 40,000-\$ 79,999$ & $\begin{array}{c}0.086 \\
(0.054)\end{array}$ & $\begin{array}{c}0.068 \\
(0.045)\end{array}$ \\
\hline Income $\$ 80,000-\$ 149,999$ & $\begin{array}{c}0.024 \\
(0.058)\end{array}$ & $\begin{array}{c}0.042 \\
(0.049)\end{array}$ \\
\hline Income $\geq \$ 150,000$ & $\begin{array}{c}0.037 \\
(0.063)\end{array}$ & $\begin{array}{c}0.007 \\
(0.053)\end{array}$ \\
\hline Some College & $\begin{array}{c}0.008 \\
(0.089)\end{array}$ & $\begin{array}{l}-0.096 \\
(0.076)\end{array}$ \\
\hline Bachelor's Deg. & $\begin{array}{c}0.205^{* *} \\
(0.093)\end{array}$ & $\begin{array}{l}0.060 \\
(0.080)\end{array}$ \\
\hline Advanced Deg. & $\begin{array}{c}0.264^{* *} \\
(0.104)\end{array}$ & $\begin{array}{c}0.036 \\
(0.092)\end{array}$ \\
\hline Mother Some College & $\begin{array}{c}0.058 \\
(0.079)\end{array}$ & $\begin{array}{c}0.033 \\
(0.066)\end{array}$ \\
\hline Mother Bachelor's Deg. & $\begin{array}{c}0.114^{* *} \\
(0.056)\end{array}$ & $\begin{array}{c}0.103^{* *} \\
(0.046)\end{array}$ \\
\hline Mother Advanced Deg. & $\begin{array}{l}0.108^{*} \\
(0.057)\end{array}$ & $\begin{array}{c}0.079 \\
(0.048)\end{array}$ \\
\hline Constant & $\begin{array}{c}0.899^{* * *} \\
(0.093)\end{array}$ & $\begin{array}{l}-0.100 \\
(0.167)\end{array}$ \\
\hline $\begin{array}{l}\text { Adjusted } R^{2} \\
N\end{array}$ & $\begin{array}{c}0.388 \\
135\end{array}$ & $\begin{array}{c}0.583 \\
135\end{array}$ \\
\hline
\end{tabular}

Standard errors reported in parentheses.

*** indicates significance at the one-percent level; ** indicates significance at the fivepercent level; * indicates significance at the ten-percent level. 
Table 8: U.S. inflation perceptions and forecasts by demographic group

\begin{tabular}{|c|c|c|c|}
\hline & past 5 years & 1-year ahead & 5-years ahead \\
\hline Male & 3.575 & 2.169 & 6.022 \\
\hline Female & 4.857 & 2.481 & 7.983 \\
\hline Age $\leq 21$ & 5.923 & 2.027 & 6.931 \\
\hline Age $22-24$ & 4.686 & 2.784 & 7.827 \\
\hline Age $25-31$ & 3.883 & 1.853 & 6.607 \\
\hline Age $\geq 32$ & 4.269 & 1.519 & 6.954 \\
\hline White & 3.949 & 1.864 & 6.270 \\
\hline Black & 5.623 & 1.310 & 7.667 \\
\hline Hispanic & 6.500 & 3.583 & 13.667 \\
\hline Asian & 3.895 & 4.327 & 5.107 \\
\hline Multiracial & 5.371 & 4.063 & 14.458 \\
\hline Other Race & 5.917 & 1.917 & 8.708 \\
\hline Not U.S.-Born & 4.013 & 2.364 & 6.362 \\
\hline U.S.-Born & 4.473 & 2.363 & 6.842 \\
\hline Income $\leq \$ 39,999$ & 4.712 & 2.860 & 6.135 \\
\hline Income $\$ 40,000-\$ 79,999$ & 3.440 & 2.519 & 7.085 \\
\hline Income $\$ 80,000-\$ 149,999$ & 5.233 & 1.331 & 8.480 \\
\hline Income $\geq \$ 150,000$ & 3.824 & 1.991 & 6.121 \\
\hline H.S. Diploma or less & 5.233 & 0.559 & 8.15 \\
\hline Some College & 4.899 & 2.545 & 9.075 \\
\hline Bachelor's Deg. & 3.983 & 1.823 & 4.945 \\
\hline Advanced Deg. & 3.762 & 4.006 & 4.729 \\
\hline
\end{tabular}


Table 9: Accuracy of U.S. inflation perceptions and forecasts

\begin{tabular}{|c|c|c|c|c|c|c|}
\hline & $\begin{array}{r}\text { past } 5 \text { years } \\
\text { abs. }\end{array}$ & $\begin{array}{l}\text { past } 5 \text { years } \\
\text { error }\end{array}$ & $\begin{array}{r}1 \text {-year ahead } \\
\text { abs. }\end{array}$ & $\begin{array}{l}1 \text {-year ahead } \\
\text { error }\end{array}$ & 5-years ahead & $\begin{array}{l}5 \text {-years ahead } \\
\text { level }\end{array}$ \\
\hline Literacy & & $\begin{array}{c}-5.922^{* * * *} \\
(1.780)\end{array}$ & & $\begin{array}{c}-3.170^{* *} \\
(1.297)\end{array}$ & & $\begin{array}{l}-5.909 \\
(4.062)\end{array}$ \\
\hline Female & $\begin{array}{l}1.729 * * \\
(0.673)\end{array}$ & $\begin{array}{l}1.230^{*} \\
(0.662)\end{array}$ & $\begin{array}{c}0.695 \\
(0.476)\end{array}$ & $\begin{array}{c}0.421 \\
(0.479)\end{array}$ & $\begin{array}{l}0.957 \\
(1.450)\end{array}$ & $\begin{array}{c}0.510 \\
(1.475)\end{array}$ \\
\hline Age $22-24$ & $\begin{array}{c}0.577 \\
(1.149)\end{array}$ & $\begin{array}{c}0.388 \\
(1.103)\end{array}$ & $\begin{array}{c}0.825 \\
(0.812)\end{array}$ & $\begin{array}{c}0.733 \\
(0.795)\end{array}$ & $\begin{array}{l}4.382^{*} \\
(2.516)\end{array}$ & $\begin{array}{c}4.082 \\
(2.512)\end{array}$ \\
\hline Age $25-31$ & $\begin{array}{c}0.298 \\
(1.260)\end{array}$ & $\begin{array}{l}-0.141 \\
(1.215)\end{array}$ & $\begin{array}{c}0.154 \\
(0.897)\end{array}$ & $\begin{array}{l}-0.041 \\
(0.881)\end{array}$ & $\begin{array}{l}6.921^{* *} \\
(2.732)\end{array}$ & $\begin{array}{l}6.369^{* *} \\
(2.745)\end{array}$ \\
\hline Age $\geq 32$ & $\begin{array}{l}1.023 \\
(1.137)\end{array}$ & $\begin{array}{c}0.358 \\
(1.108)\end{array}$ & $\begin{array}{l}1.521^{*} \\
(0.803)\end{array}$ & $\begin{array}{l}1.160 \\
(0.799)\end{array}$ & $\begin{array}{c}6.526^{* * *} \\
(2.430)\end{array}$ & $\begin{array}{l}5.900^{* *} \\
(2.456)\end{array}$ \\
\hline Black & $\begin{array}{l}1.140 \\
(1.057)\end{array}$ & $\begin{array}{c}0.523 \\
(1.030)\end{array}$ & $\begin{array}{c}0.361 \\
(0.746)\end{array}$ & $\begin{array}{l}0.027 \\
(0.743)\end{array}$ & $\begin{array}{l}3.036 \\
(2.254)\end{array}$ & $\begin{array}{c}2.379 \\
(2.288)\end{array}$ \\
\hline Hispanic & $\begin{array}{c}1.352 \\
(2.150)\end{array}$ & $\begin{array}{l}1.323 \\
(2.061)\end{array}$ & $\begin{array}{c}0.388 \\
(1.518)\end{array}$ & $\begin{array}{c}0.383 \\
(1.486)\end{array}$ & $\begin{array}{l}9.324^{* *} \\
(4.582)\end{array}$ & $\begin{array}{l}9.271^{* *} \\
(4.560)\end{array}$ \\
\hline Asian & $\begin{array}{l}-1.413 \\
(1.076)\end{array}$ & $\begin{array}{l}-1.398 \\
(1.031)\end{array}$ & $\begin{array}{l}-0.419 \\
(0.786)\end{array}$ & $\begin{array}{l}-0.341 \\
(0.770)\end{array}$ & $\begin{array}{c}0.649 \\
(2.302)\end{array}$ & $\begin{array}{c}0.632 \\
(2.291)\end{array}$ \\
\hline Multiracial & $\begin{array}{c}0.501 \\
(1.158)\end{array}$ & $\begin{array}{c}0.595 \\
(1.110)\end{array}$ & $\begin{array}{l}1.215 \\
(0.818)\end{array}$ & $\begin{array}{l}1.257 \\
(0.800)\end{array}$ & $\begin{array}{l}5.553^{* *} \\
(2.534)\end{array}$ & $\begin{array}{l}5.590^{* *} \\
(2.522)\end{array}$ \\
\hline Other Race & $\begin{array}{c}0.541 \\
(1.590)\end{array}$ & $\begin{array}{l}-0.326 \\
(1.547)\end{array}$ & $\begin{array}{c}0.075 \\
(1.123)\end{array}$ & $\begin{array}{l}-0.390 \\
(1.115)\end{array}$ & $\begin{array}{c}2.562 \\
(3.389)\end{array}$ & $\begin{array}{l}1.689 \\
(3.425)\end{array}$ \\
\hline Not US-Born & $\begin{array}{l}-0.088 \\
(0.935)\end{array}$ & $\begin{array}{c}0.267 \\
(0.902)\end{array}$ & $\begin{array}{l}-0.352 \\
(0.666)\end{array}$ & $\begin{array}{l}-0.194 \\
(0.655)\end{array}$ & $\begin{array}{c}0.161 \\
(1.991)\end{array}$ & $\begin{array}{c}0.518 \\
(1.996)\end{array}$ \\
\hline Some College & $\begin{array}{c}-0.034 \\
(1.462)\end{array}$ & $\begin{array}{c}0.666 \\
(1.417)\end{array}$ & $\begin{array}{c}0.521 \\
(1.033)\end{array}$ & $\begin{array}{c}0.909 \\
(1.023)\end{array}$ & $\begin{array}{l}-0.205 \\
(3.117)\end{array}$ & $\begin{array}{c}0.520 \\
(3.142)\end{array}$ \\
\hline Bachelor's Deg. & $\begin{array}{l}-0.919 \\
(1.531)\end{array}$ & $\begin{array}{c}0.138 \\
(1.501)\end{array}$ & $\begin{array}{c}-1.376 \\
(1.081)\end{array}$ & $\begin{array}{l}-0.820 \\
(1.082)\end{array}$ & $\begin{array}{c}-6.450^{*} \\
(3.284)\end{array}$ & $\begin{array}{l}-5.263 \\
(3.368)\end{array}$ \\
\hline Advanced Deg. & $\begin{array}{l}-1.701 \\
(1.697)\end{array}$ & $\begin{array}{c}-0.090 \\
(1.697)\end{array}$ & $\begin{array}{c}-1.980 \\
(1.207)\end{array}$ & $\begin{array}{l}-1.067 \\
(1.239)\end{array}$ & $\begin{array}{c}-7.791^{* *} \\
(3.616)\end{array}$ & $\begin{array}{l}-6.162 \\
(3.768)\end{array}$ \\
\hline Mother Some College & $\begin{array}{c}-1.558 \\
(1.304)\end{array}$ & $\begin{array}{c}-1.323 \\
(1.252)\end{array}$ & $\begin{array}{l}-0.180 \\
(0.921)\end{array}$ & $\begin{array}{l}-0.063 \\
(0.903)\end{array}$ & $\begin{array}{l}-3.509 \\
(2.827)\end{array}$ & $\begin{array}{l}-3.263 \\
(2.818)\end{array}$ \\
\hline Mother Bachelor's Deg. & $\begin{array}{c}-2.562^{* * *} \\
(0.919)\end{array}$ & $\begin{array}{c}-2.365^{* * *} \\
(0.883)\end{array}$ & $\begin{array}{l}-0.182 \\
(0.650)\end{array}$ & $\begin{array}{l}-0.090 \\
(0.637)\end{array}$ & $\begin{array}{c}0.587 \\
(2.015)\end{array}$ & $\begin{array}{c}0.758 \\
(2.009)\end{array}$ \\
\hline Mother Advanced Deg. & $\begin{array}{l}-1.526 \\
(0.941)\end{array}$ & $\begin{array}{l}-1.203 \\
(0.907)\end{array}$ & $\begin{array}{l}-0.322 \\
(0.666)\end{array}$ & $\begin{array}{l}-0.135 \\
(0.656)\end{array}$ & $\begin{array}{l}1.306 \\
(2.066)\end{array}$ & $\begin{array}{l}1.605 \\
(2.066)\end{array}$ \\
\hline Income $\$ 40,000-\$ 79,999$ & $\begin{array}{l}-0.693 \\
(0.891)\end{array}$ & $\begin{array}{l}-0.604 \\
(0.854)\end{array}$ & $\begin{array}{c}0.194 \\
(0.629)\end{array}$ & $\begin{array}{l}0.237 \\
(0.616)\end{array}$ & $\begin{array}{c}1.637 \\
(1.909)\end{array}$ & $\begin{array}{c}1.652 \\
(1.899)\end{array}$ \\
\hline Income $\$ 80,000-\$ 149,999$ & $\begin{array}{c}0.866 \\
(0.952)\end{array}$ & $\begin{array}{c}0.899 \\
(0.913)\end{array}$ & $\begin{array}{l}-0.016 \\
(0.675)\end{array}$ & $\begin{array}{l}-0.021 \\
(0.661)\end{array}$ & $\begin{array}{l}1.052 \\
(2.127)\end{array}$ & $\begin{array}{c}0.994 \\
(2.117)\end{array}$ \\
\hline Income $\$ 150,000$ or more & $\begin{array}{l}-0.990 \\
(1.034)\end{array}$ & $\begin{array}{l}-0.988 \\
(0.991)\end{array}$ & $\begin{array}{l}-0.392 \\
(0.730)\end{array}$ & $\begin{array}{l}-0.398 \\
(0.715)\end{array}$ & $\begin{array}{c}0.967 \\
(2.223)\end{array}$ & $\begin{array}{c}0.893 \\
(2.213)\end{array}$ \\
\hline Constant & $\begin{array}{c}3.849 * * \\
(1.529)\end{array}$ & $\begin{array}{c}7.261^{* * *} \\
(1.789)\end{array}$ & $\begin{array}{c}2.306^{* *} \\
(1.080)\end{array}$ & $\begin{array}{c}4.128^{* * *} \\
(1.293)\end{array}$ & $\begin{array}{c}2.976 \\
(3.259)\end{array}$ & $\begin{array}{c}6.413 \\
(4.013)\end{array}$ \\
\hline Adjusted $\mathrm{R}^{2}$ & 0.053 & 0.130 & 0.068 & 0.107 & 0.059 & 0.068 \\
\hline $\mathrm{N}$ & 134 & 134 & 133 & 133 & 132 & 132 \\
\hline
\end{tabular}

Standard errors reported in parentheses.

*** indicates significance at the one-percent level; ${ }^{* *}$ indicates significance at the five-percent level; ${ }^{*}$ indicates significance at the ten-percent level. 


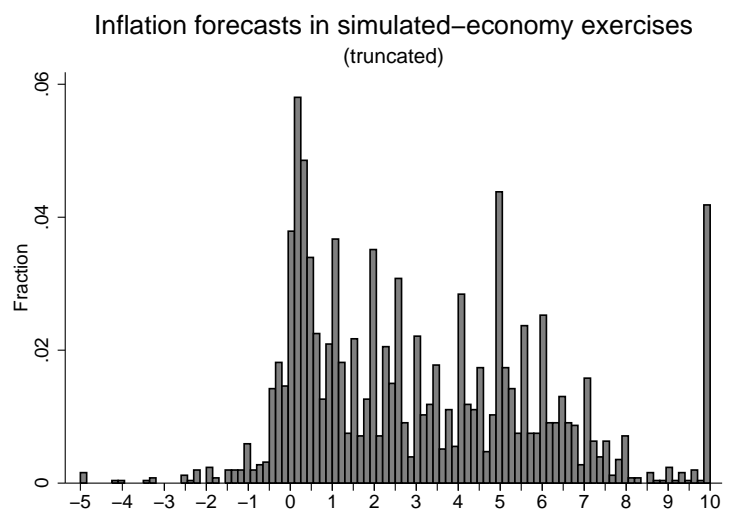

Figure 1
Signed forecast errors in simulated-economy exercises

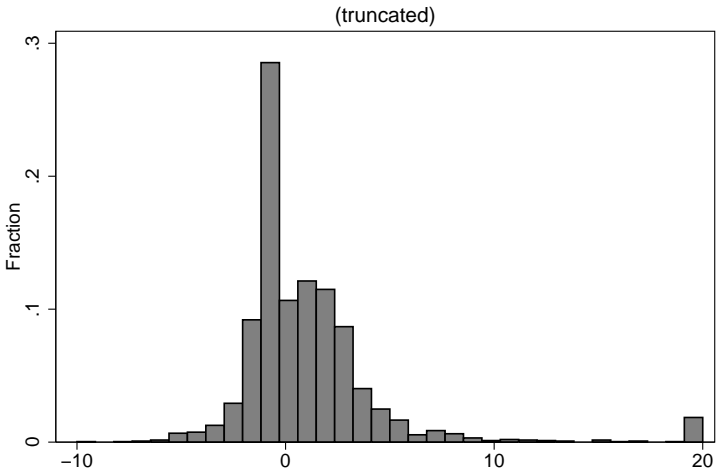

Figure 2

Comparison of mean errors (by exercise) across forecast horizons

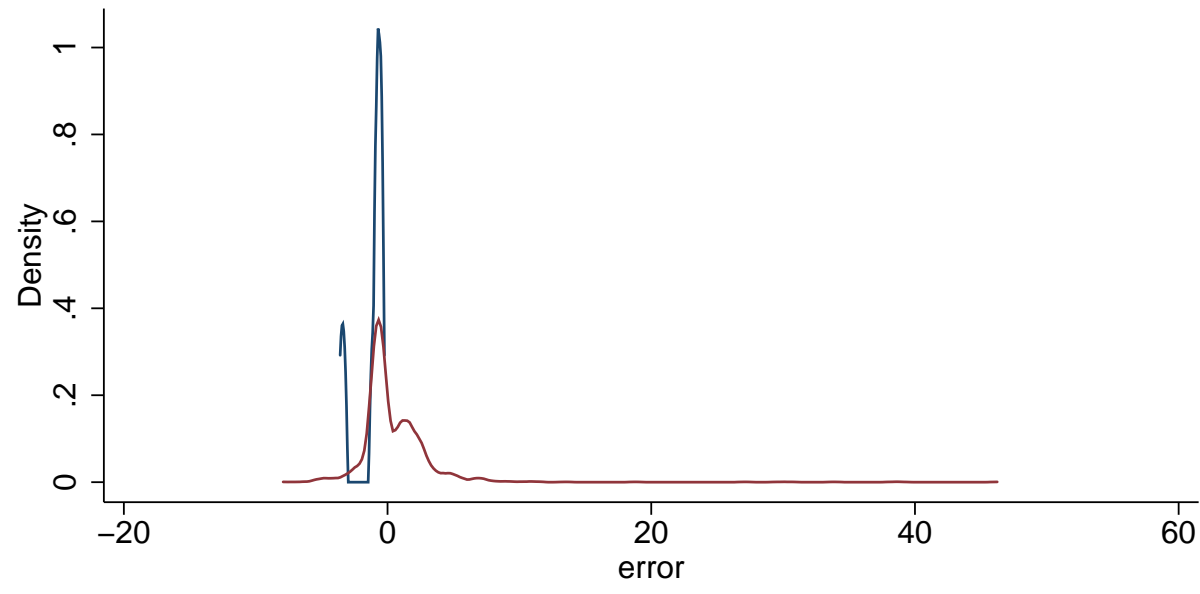

1 Year Forecasts 5 Year Forecasts

kernel $=$ epanechnikov, bandwidth $=0.1837$

Figure 3 


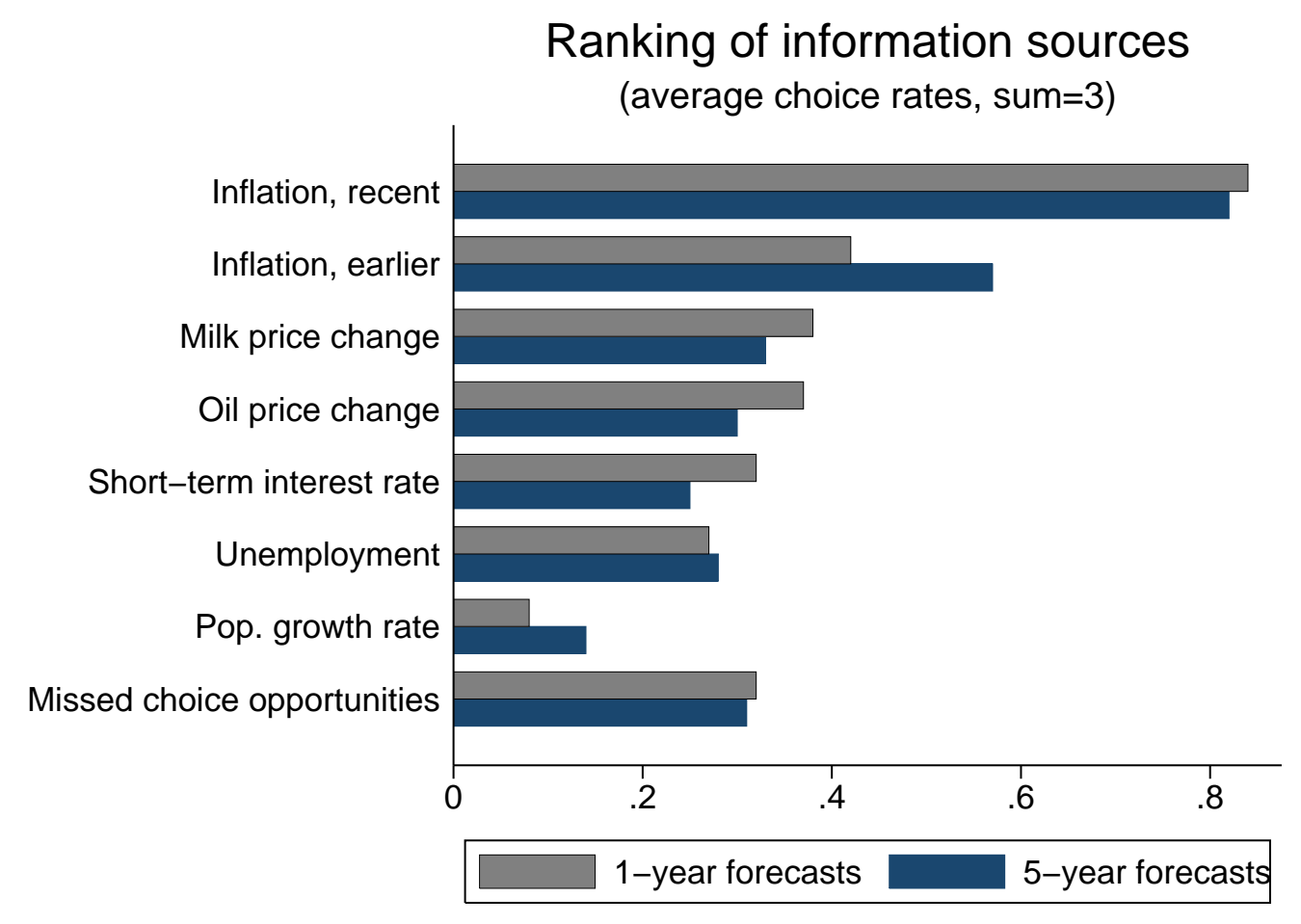

Figure 4

Inflation perceptions and forecasts:

Experiment sample vs. University of Michigan survey

polling date December 2009

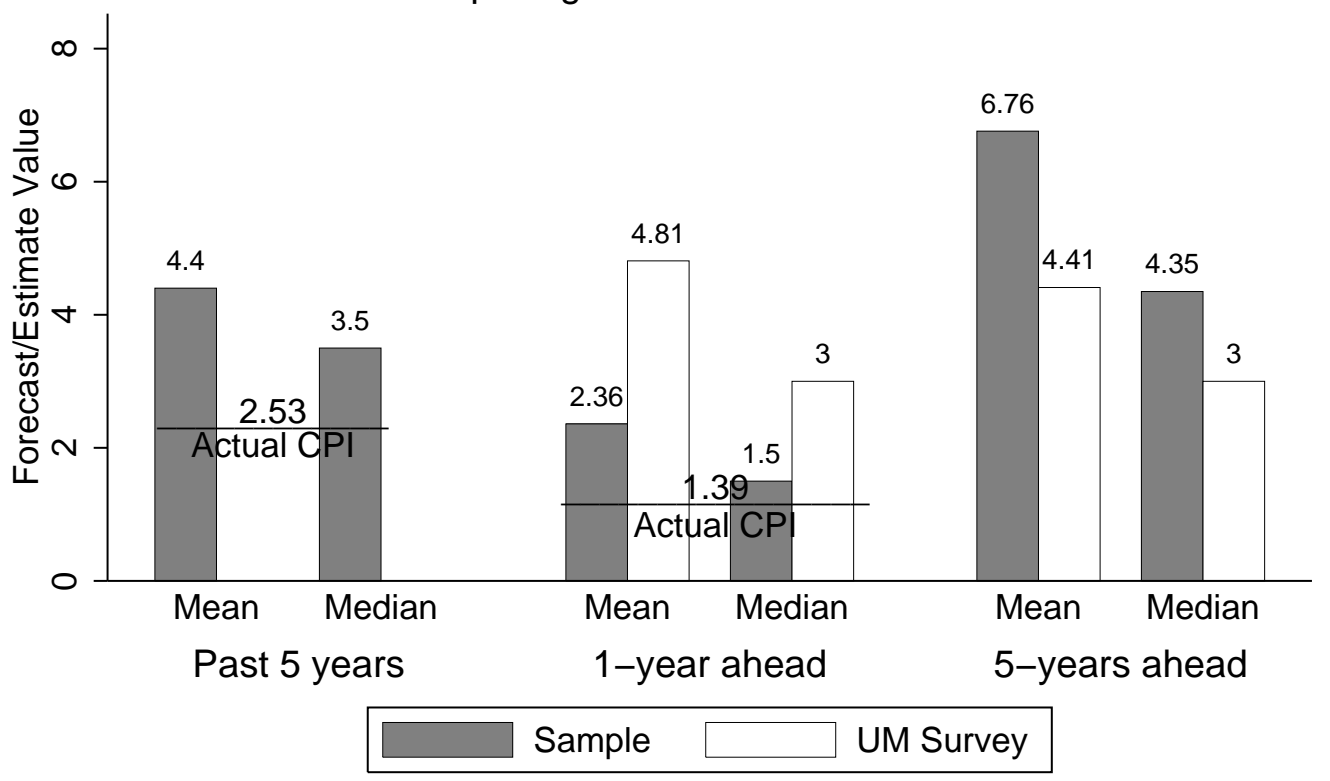

Figure 5 


\section{Appendix}

Contents:

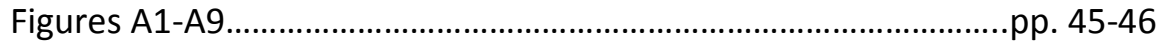

Economic literacy questionnaire...................................................pp. 47-49 


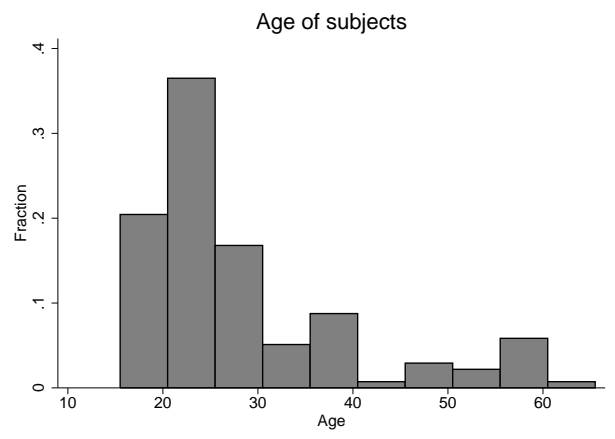

Figure A1

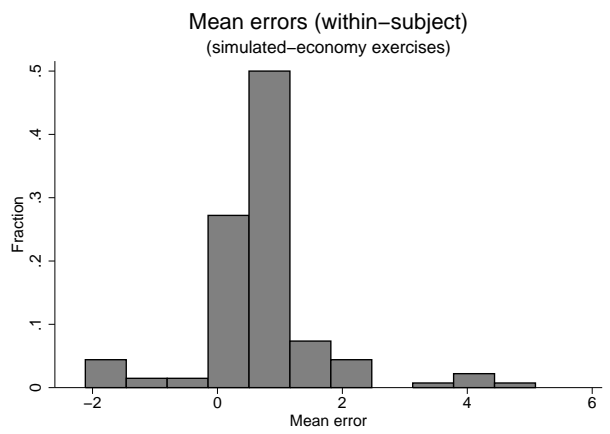

Figure A3

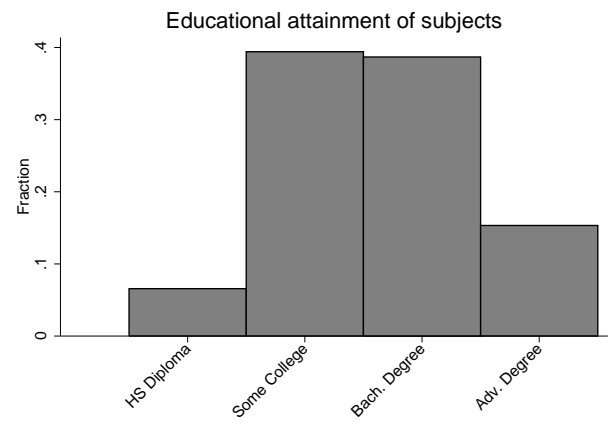

Figure A2

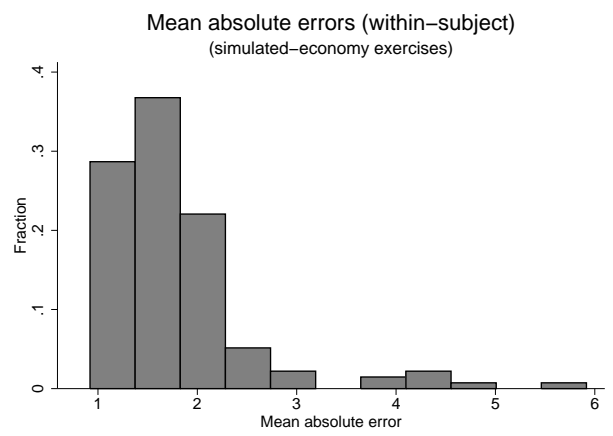

Figure A4 


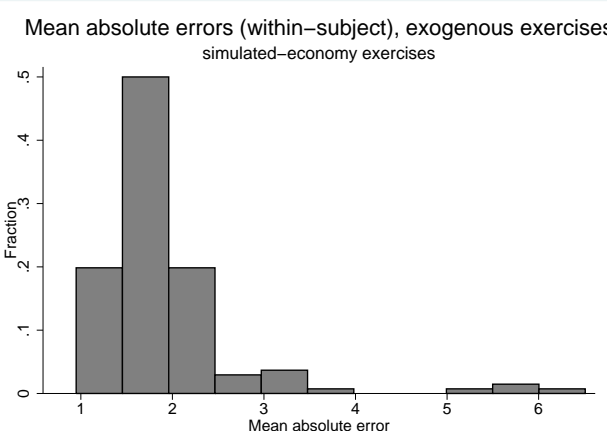

Figure A5

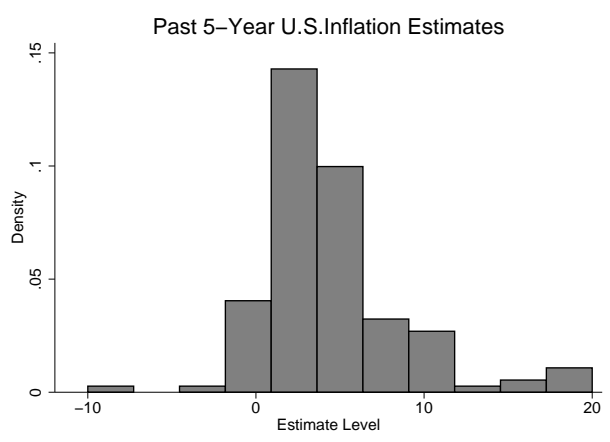

Figure A7
Mean absolute errors (within-subject), endogenous exercises

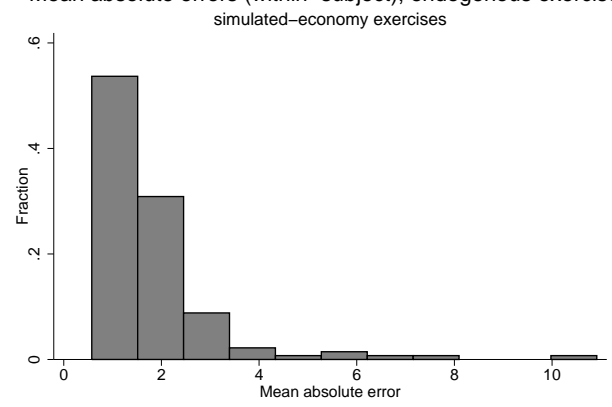

Figure A6

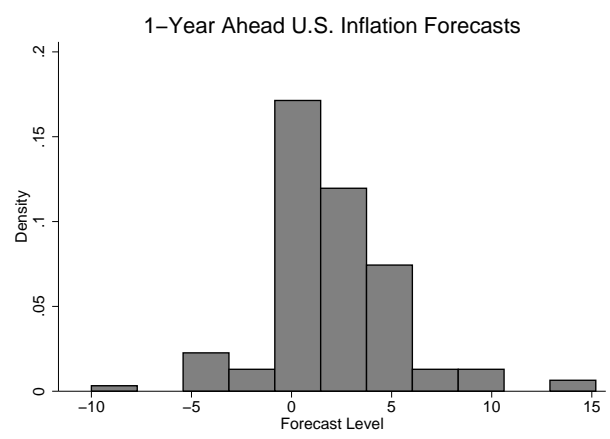

Figure A8

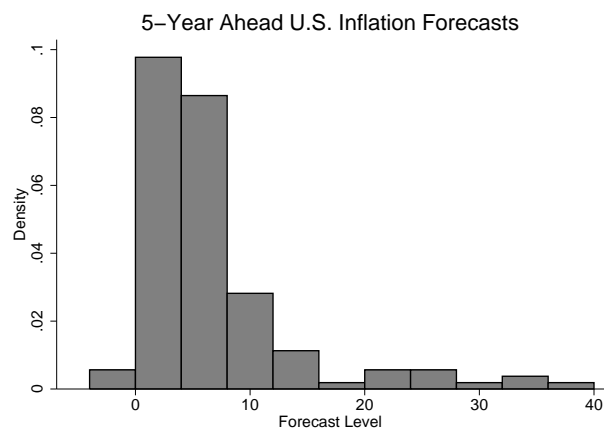

Figure A9 
Questionnaire on economic and financial literacy. (Regarding the analysis in Section 4.d. above and in Table 8, questions 1-7 were classified as testing "monetary literacy," questions 8-10 and 12-15 were classified as testing "financial literacy," and questions 11 and 16 tested "pure numeracy.")

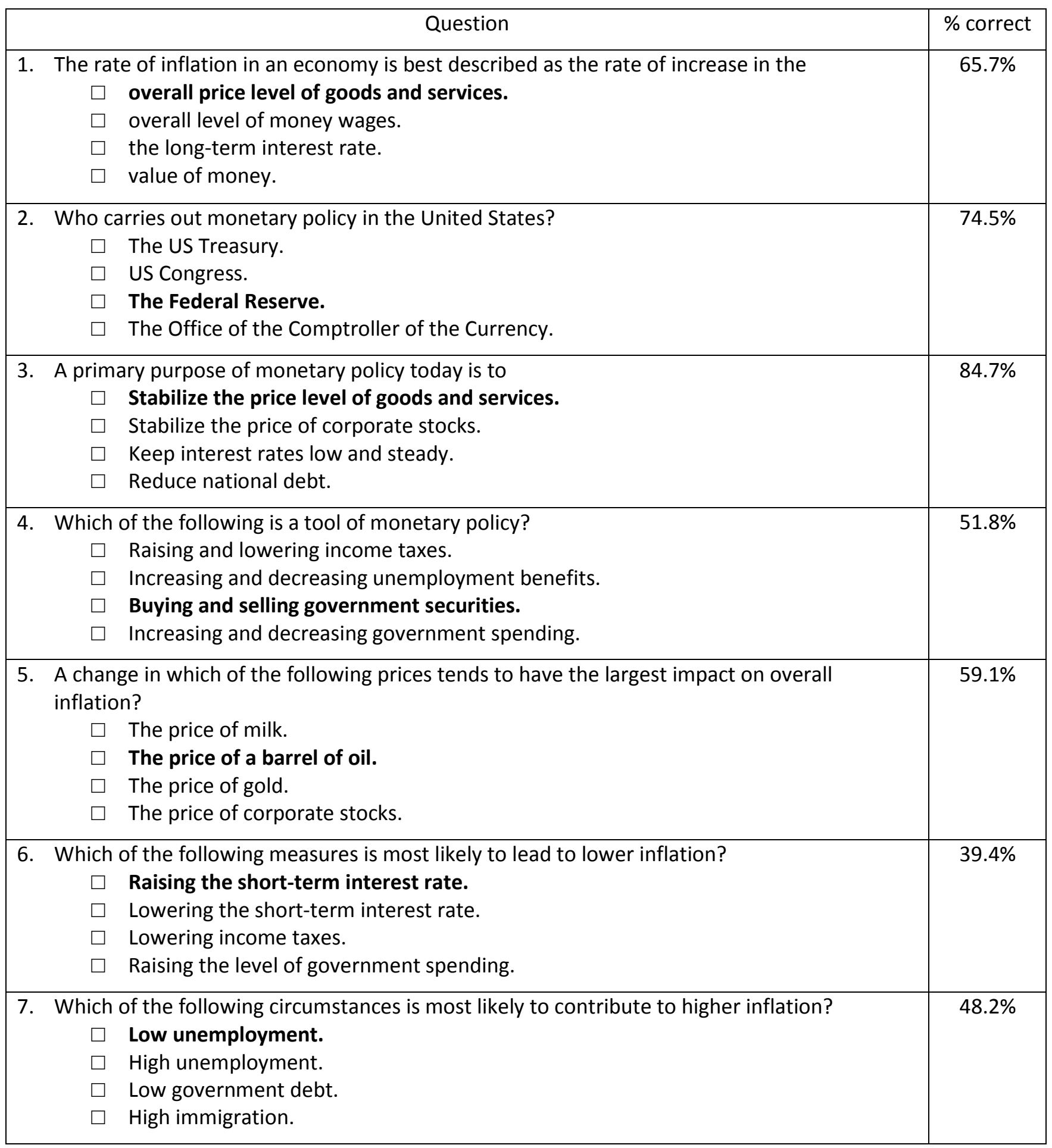




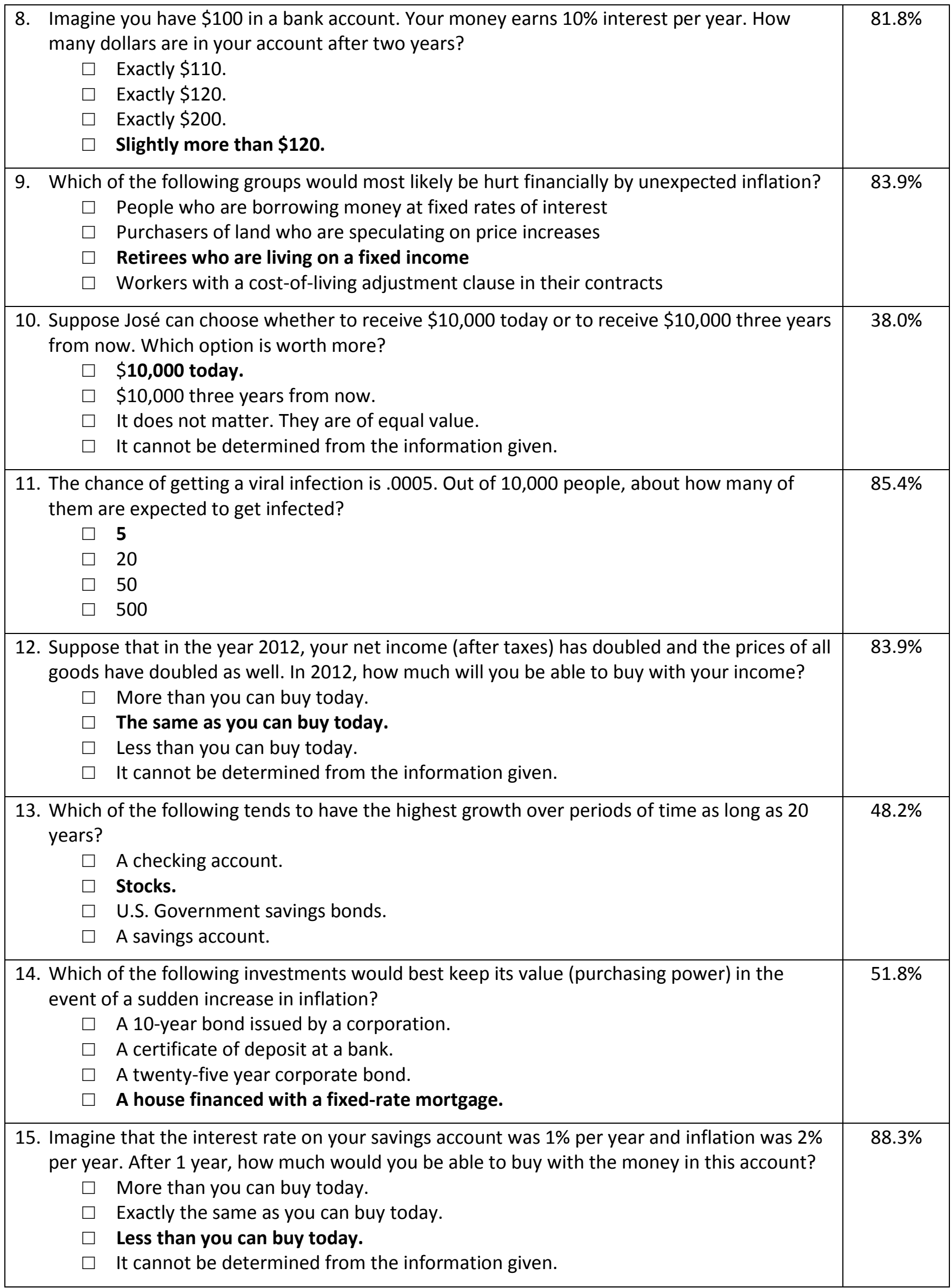


16. In the ACME sweepstakes, the chance of winning a car is 1 in 1,000. What percent of tickets

$73.7 \%$ of ACME sweepstakes win a car?

$\square \quad 0.01 \%$

$\square \quad 0.1 \%$

$\square \quad 1 \%$

$\square \quad 10 \%$ 